\title{
Research Paper \\ A Study of the Components of Brain-based Curriculum model in Pre-school and its Accreditation: A Quantitative Research
}

\author{
Ramin Nozohouri ${ }^{* 1}$, Eskandar Fathiazar ${ }^{2}$, Youef Adib ${ }^{2}$, Hasan Bafandeh ${ }^{3}$, Somayyeh Rasouli ${ }^{4}$ \\ 1. Ph.D. of Curriculum, Faculty of Education and Psycholog, University of Tabriz, Iran \\ 2. Professor, Department of Education, Faculty of Education and Psycholog, University of Tabriz, Iran \\ 3. Assistant Professor, Department of Psychology, Faculty of Education \& Psychology, Azarbaijan Shahid Madani University, Tabriz, \\ Iran \\ 4. Ph.D. Student of Educational Psychology, Faculty of Education and Psychology, University of Tabriz, Iran
}

Citation: Nozohouri R, Fathiazar E, Adib Y, Bafandeh H, Rasouli S. A study of the components of brain-based curriculum model in pre-school and its accreditation: a quantitative research. J Child Ment Health. 2021; $8(2): 30-45$.

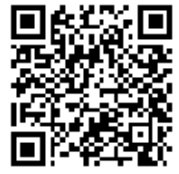

URL: http://childmentalhealth.ir/article-1-742-en.html

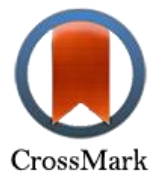

$10.52547 / \mathrm{jcmh} .8 .2 .30$ 20.1001.1.24233552.1400.8.2.1.2

\section{A R T I C L E I N F O}

\section{Keywords:}

Pre-school education, curriculum, brain-based curriculum model

Received: 4 Jan 2019

Accepted: 1 Jun 2019

Available: 11 Sep 2021

\section{A B S T R A C T}

Background and Purpose: Brain-based learning refers to teaching methods, lesson planings, and school programs that are based on the latest scientific research about how the brain learns, including such factors as cognitive, socially, and emotionally development. This research aimed to study the components of the brain-based curriculum model in pre-school and its accreditation.

Method: This study examines the core components of the brain-based curriculum with a qualitative approach and a method of subject analysis. To identify and extract curriculum items emphasizing the brain-based approach in preschool, literature of pre-school curriculum, and curriculum based on the brain and the viewpoints of neuroscience and educational experts were used. The method of information analysis was to describe the basics and theoretical inquiry and deduction.

Results: The findings indicated that the content of the curriculum objectives in this program relies on three main cognitive, attitudinal, and skillful structures. In the educational content, fine arts, learning social-emotional skills, learning language and math, life skills, safety, and experiential sciences were identified, in teaching and learning strategies, using activity-based strategies, art, participatory learning, direct teaching, and independent learning strategies and thinking skills and technology implementation strategies were identified. Considering the diagnostic, process, and evaluation, the use of various evaluation methods was considered by this model. The validity of suggested patterns was evaluated using the content validity ratio and the Lavasheh table. Finally, the validity of the proposed model was confirmed by a CVR $=0.84$.

Conclusion: The designed curriculum pays attention to the various dimensions including purpose, content, methodology, and evaluation, and its use in the preschool is recommended.

* Corresponding author: Ramin Nozohouri, Ph.D. of Curriculum, Faculty of Education and Psycholog, University of Tabriz, Iran.

E-mail: Nozhoori@gmail.com

Tel: (+98) 4133341300

2476-5740/ @ 2021 The Authors. This is an open access article under the CC BY-NC-ND license

(https://creativecommons.org/licenses/by-nc-nd/4.0/). 


\section{Extended Abstract}

\section{Introduction}

Brain-based learning, or mind science, is a learning-related concept that seeks to design natural processes to maximize effective and efficient learning. Brain-based learning is the type of learning. It is commensurate with the normal functioning of the brain (2). The brain-based approach includes twelve principles of teaching and learning. These principles are summarized as follows: 1 . The brain is a parallel processor; 2 . The learning engages the entire physiology; 3 . The search for meaning is innate; 4 . The search for meaning occurs through patterning; 5. Emotions are critical to patterning; 6 . The brain processes parts and wholes simultaneously; 7. Learning involves both focused attention and peripheral perception; 8 . Learning always involves conscious and unconscious processes, 9. There are at least two different types of memory: spatial (autobiographical) and rote learning (taxon memory); 10. Learning is developmental; 11. Learning is enhanced by challenge and inhibited by threat; 12 . Each brain is unique and its characteristics, needs, unique hopes, motivations, talents, and level of intelligence (2).

Different societies implement different educational models in educational centers of preschoolers, according to different attitudes, cultures, and values. Currently, the models used rely more on the child's cognitive development, which includes predetermined aims, application of practice and repetition methods, content regardless of the child's interests, educational tools disproportionate to the goals, scheduling of the learning process, limiting the environment. Learning to a specific place is a less organized activity (8).

We can mention the research of Mohammadi Farsani (9), Talkhabi (11), among the research on brain-based learning in different elementary courses, the curriculum model derived from brain-based learning also includes studies such as Suarsana (12), Akyurek \& Afacan (13), and McCarthy (18).

Researching in this area is valuable and essential, due to the role and importance of the brain in the teaching-learning process and less attention of previous models to the dimensions and practical aspects of brain-based learning and mental functions, memory, emotions. Therefore, the critical questions in this study are: What are the core components of the brainbased curriculum in preschool? And is the proposed model valid?

\section{Method}

The present study is qualitative research. To identify and extract the characteristics of curriculum components with emphasis on brain-based approach in preschoolers, studying and review of the literature of preschool curricula, brain-based curriculum and we asked for the opinions of experts in educational sciences and neuroscience. In the first stage, to achieve a theoretical framework, the theoretical foundations of the brain-based curriculum were studied in sources, books, articles, and other sources related to the research title. Also, by searching the internet and databases such as ISI, Eric, ScienceDirect, Irandoc, PubMed efforts were made to use wellcited research works and new sources and articles by using the keywords "brain-based learning", "brain-based curriculum", and the equivalent of these terms. To explain the theoretical foundations and identify the characteristics of the brain-based curriculum model, based on the "synthesis research" method, theoretical and experimental research sources, the brain-based curriculum was studied. To design the desired model, interviews were conducted with experts in educational sciences and neuroscience about the characteristics of the core components of the curriculum (objectives, content, learning strategies, and evaluation). Then, the information was extracted, analyzed, and combined. Finally, to determine the validity of the designed model, the proposed model was provided to experts and specialists in neuroscience and educational sciences and curriculum planners, and the validity of the model was measured through the content validity ratio (CVR).

\section{Results}

Research Question 1: What are the characteristics of the core components of a brain-based curriculum in preschool? A) Objectives: The obtained information of the questions of the viewpoints about the objectives of the brain-based curriculum of educators and experts are summarized in Table 1.

Table 1. The core and sub-themes of the curriculum objectives

Main themes

Type of aims

How to setting the goals

\section{Sub-themes}

Paying comprehensive attention to the needs and developmental dimensions of learners

Developing the functional, processual, and situational skills

Developing language skills such as listening and speaking

Develop physical skills, health

Developing life skills

Setting the goals to maintain the integrity of the brain

Pay attention to emotion, memory, intelligence, and perception

According to the characteristics and abilities and individual differences of students

Relating goals to the student's real life

Setting the goals according to educational results and efficiencies

Considering mental abilities and skills

setting the goals based on learners' skills 
The results of the interviews with the educators and experts about the objectives in Table 1 show that the guidelines obtained from the analysis of the interviewees' answers are finally placed in 3 main themes and 14 sub-themes.
B) Content: The obtained information of the questions of the viewpoints about the content and organization of the brainbased curriculum of educators and experts are summarized in Table 2.

Table 2. The core themes and sub-themes of the curriculum content from the perspective of educators and experts

\begin{tabular}{|c|c|}
\hline Main themes & Sub-themes \\
\hline Type of content & $\begin{array}{c}\text { Considering appropriate and necessary content such as fine arts, mathematics, etc } \\
\text { Activity-oriented }\end{array}$ \\
\hline Content Features & Content responds to the needs of Preschoolers \\
\hline \multirow{10}{*}{ Suggestions } & $\begin{array}{l}\text { Paying attention to the individual differences of the preschoolers } \\
\text { Holding educational courses }\end{array}$ \\
\hline & Developing content based on brain-based curriculum goals \\
\hline & Variety of educational methods in presenting content \\
\hline & Coach's ability to deliver content \\
\hline & Employing capable coaches \\
\hline & Paying attention to the principles of brain-based learning \\
\hline & Paying attention to the learning structure of Preschoolers \\
\hline & The role of the coach as a facilitator \\
\hline & Using an integrated method in organizing content \\
\hline & Using the extracurricular activities \\
\hline
\end{tabular}

The results of reviewing the information related to the content of the curriculum show that the guidelines obtained from the analysis of the interviewees' answers are finally placed in 3 main themes and 14 sub-themes.
C) Teaching-learning strategies: The obtained information of the questions of the viewpoints about the teaching-learning strategies of the brain-based curriculum of educators and experts are summarized in Table 3.

Table 3. The core and subsidiary themes of learning teaching strategies

\begin{tabular}{cc}
\hline Main themes & Sub-themes \\
\hline Types of strategies & $\begin{array}{c}\text { Activity-based strategies } \\
\text { Art-based strategies } \\
\text { Participation-based strategies } \\
\text { Direct learning strategies } \\
\text { Independent learning strategies } \\
\text { Strategies based on exploration patterns } \\
\text { Thinking Skills Strategies } \\
\text { Strategy based on learning styles } \\
\text { Factors affecting the type of strategy }\end{array}$ \\
& $\begin{array}{c}\text { Technological and media application strategy } \\
\text { Consider the individual differences of newcomers } \\
\text { Pay attention to the needs of preschoolers } \\
\text { Content types }\end{array}$ \\
\hline
\end{tabular}

The results of reviewing the information related to teachinglearning strategies with educators and experts show that the guidelines obtained from the analysis of the interviewees' responses are finally placed in 2 main themes and 12 subthemes.
D) Evaluation: The obtained information of the questions of the viewpoints about the characteristics and types of evaluation of the brain-based curriculum of educators and experts are summarized in Table.

Table 4. The core and subsidiary themes of learning Evaluation

Main themes

Evaluation features

\section{Sub-themes}

\section{Fits the principles of brain-based learning}

Indirect

Pay attention to individual learners' differences

Be processed

Activity-oriented

Pay attention to competencies and capabilities 


\section{Quarterly Journal of \\ Child Mental Health}

Vol. 8, No. 2, Summer 2021

\author{
Applications \\ Types of evaluation \\ Evaluation tools
}

Moving away from traditional methods of evaluation

Creating awareness in decision making regarding the status of programs Identify the strengths and weaknesses of new students and educational methods Empowering coaches to evaluate themselves

Decide on promotion

Pree evaluation Diagnostic

Formative evaluation

Terminal evaluation

Self-assessment

Open evaluation

Project evaluation

Observations

Interviews

Exams

Checklist
The results of examining the question related to the evaluation methods with the educators and experts in Table 4 show that the guidelines obtained from the analysis of the interviewees' answers are finally placed in 4 main themes and 22 sub-themes. The second research question: Is the proposed model of the preschool curriculum valid?

We separately tested the validity of the proposed brain-based curriculum model for each of the components. According to the number of participants (12 people) and based on the values of the table, the items whose content had a validity ratio of more than 0.56 were accepted. The results confirmed the content validity ratio $(\mathrm{CVR}=0.84)$ and content validity index $(\mathrm{CVI}=$ 0.79 ) of the proposed model of the brain-based curriculum in preschoolers.

\section{Conclusion}

The present study aimed to design a model of the brain-based curriculum in preschool and its validation. The brain-based model is designed according to the principles of brain-based learning and in the form of four core components: objectives, content, teaching-learning methods, and evaluation. According to the results of a systematic review of specialized sources and texts as well as qualitative content analysis of interviews in this study, the characteristics of these four core components were expressed by tables 1 to 4 . The objectives of the brain-based curriculum in this study are supported by Farsani (9) and Talkhabi (11) studies. They indicate that the objects of the curriculum should be related to the real-life of the students. The curriculum model in this study has goals that are common to the aims of the designed model of Adib and Piri (7) called the developmental model, including aims such as developing emotional skills, mental development, helping physical development, and language learning in pointed out two patterns. The results of McCarthy's research (18) include activities and educational materials that stimulate the left and right hemispheres of the brain. The information obtained from the literature reviewing in this study also illustrates that preschool content should pay attention to the development of mental skills in both hemispheres. The improvement in mathematical and musical skills is emphasized, as is the case in the studies of Suarsana, Made, Putu, and Suparta (12) and Akyurek and Afacan (13). The learning strategies reported in this study are consistent with Duman strategies (14) and McCarthy strategies (18).

According to the results, it could be emphasized that designing, compiling, and predicting a set of different learning experiences and opportunities in line with the existing diversity in brain-based learning, make the learning process a natural and attractive phenomenon. Therefore, we suggest practitioners and educators consider the proposed model during the educating process.

\section{Ethical Considerations}

Compliance with ethical guidelines: This research is extracted from Ph.D. dissertation of Mr. Ramin Nozohouri with the code 2538244 and dated 2019-5-29 in the field of curriculum Development of Tabriz.

Funding: This research was conducted without sponsor and in the form of a doctoral dissertation.

Authors' contribution: The first author conducted this research under the supervising and advising of the other authors.

Conflict of interest: Doing this research has not led to any conflict of interest for the authors, and the results have been reported quite clearly.

Acknowledgments: We would like to thank all the officials of the Organization of Education of Tabriz for coordinated with the school for the implementation of education and research, as well as the administrative staff, teachers, and all Specialists who helped us in the conducting of this project. 


\title{
بررسى عناصر الكوى برنامه درسى مبتنى بر مغز در دوره يِشدبشتانى و اعتباربخشى آن (يُوهش كيفى)
}

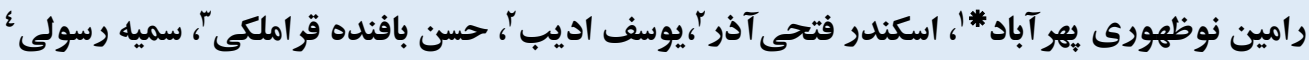

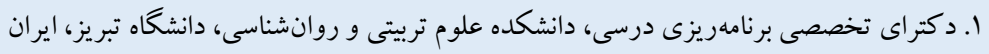

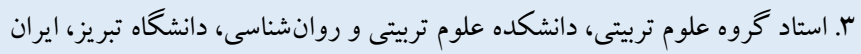

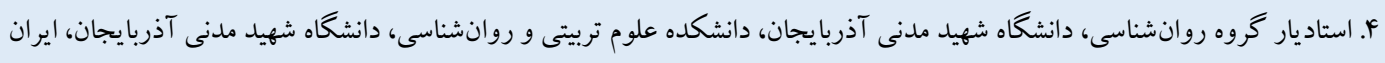

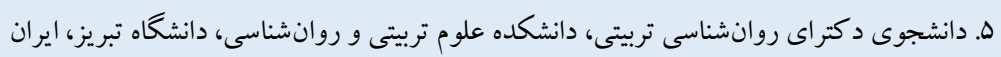

\begin{tabular}{|c|c|}
\hline جكيده & 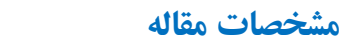 \\
\hline زمينه و هدف: ياد گيرى مبتى بر مغز به روشهاى آموزشى، طرحهاى درس و برنامههاى مدرسهاى اشـاره دارد كه بر اسـاس آخرين & كليدوازهها: \\
\hline يُزوهشهاى علمى شـامل نحوه يادگيرى مغز از جمله تحول شناختى، اجتماعى، و احساسى است. هدف اين يُزوهش، بررسى عناصر الكوى & 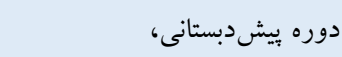 \\
\hline برنامه درسى مبتنى بر مغز در دوره يِيشدبستانى و اعتباربخشى آن است. & 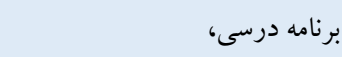 \\
\hline روش: اين بُروهش با روى آورد كيفى و روش تحليل مضـمون به بررسى عناصر اساسى برنامه درسى مبتى بر مغز مى يردازد. براى شناسايى & الكوى برنامه درسى مبتنى بر مغز \\
\hline و استخراج مضـامين برنامه درسى در دوره يِيشدبستانى، از اسـناد و مداركى برنامههاى درسى دوره يِيشدبستانى و برنامه مبتنى بر مغز و & \\
\hline نظرات متخصصان علوم اعصاب و علوم ترييتى استفاده شد. روش تحليل اطلاعات، توصيف مبانى و تحليل و استتاج نظرى بود. & \\
\hline يافتهها: مضـامين ناظر بر اهداف برنامه درسى در اين برنامه بر سـه سـازه اصلى شـناختى، نغرشى، و مهارتى تكيه دارد. در بخش محتواى & \\
\hline آموزشى، هنرهاى زيبا، ياد گيرى مهارتهاى اجتماعى- هيجانى، ياد گيرى زبان و رياضى، مهارتهاى زندگى، ايمنى، و علوم تجربى؛ و در & \\
\hline بخش راهبردهاى ياددهى و ياد گيرى، استفاده از راهبردهاى مبتنى بر فعاليت، مبتى بر هنر، ياد گيرى مشار كتى، آموزش مستقيم، راهبردهاى & \\
\hline يادكيرى مستقل و مهارت تفكر، و راهبرد كاربست فناورانه شناسايى شدند. توجه به ارزشيابىهاى تشخيصى، فرايندى و بر آيندى، و استفاده & \\
\hline از روشهاى ارزشيابى گوناكون، مورد توجه اين الكو بود. روايى الكوهاى بيشـنهادى با استفاده از فرمول نسبت روايى محتوا و جدول لاشه & \\
\hline 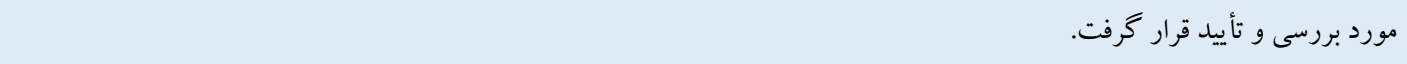 & \\
\hline نتيجه كيرى: برنامه درسى طراحى شـده ناظر بر توجه به ابعاد مختلف برنامه درسى از جمله هدف، محتوا، روش و ارزشيابى بوده و اعتبار & 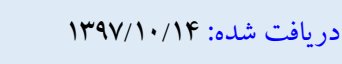 \\
\hline الكوى مذكور توسط متخصصان و صاحبنظران بررسى و مورد تأييد قرار كرفت؛ در نتيجه استفاده از آن در دوره بيش دبستانى ييشنهاد & 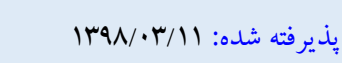 \\
\hline 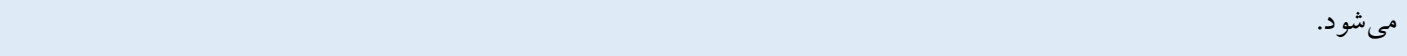 & 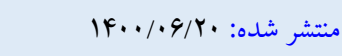 \\
\hline
\end{tabular}

* نويسنده مسئول: رامين نوظهورى بهر آباد، دكتراى تخصصى برنامهريزى درسى، دانشكده علوم تربيتى و روانشناسى، دانشكاه تبريز، ايران.

رايانه: Nozhoori@gmail.com

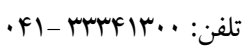




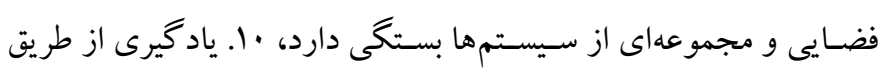

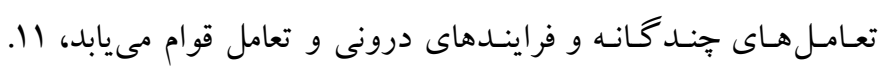

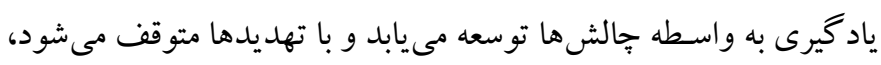

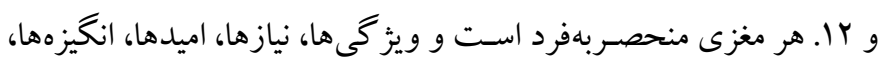

$$
\text { استعدادها و سطح هوشى منحصربه فردى دارد (Y). }
$$

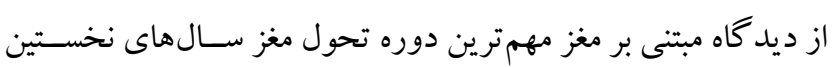

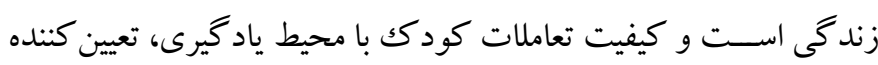

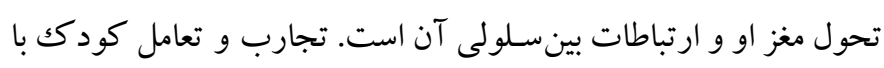

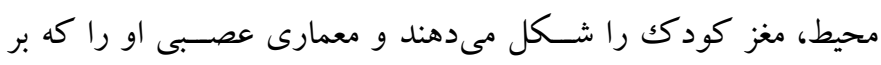

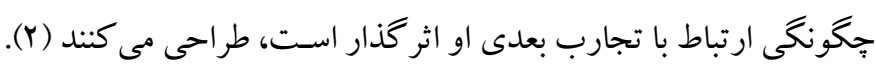

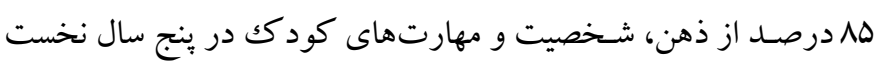

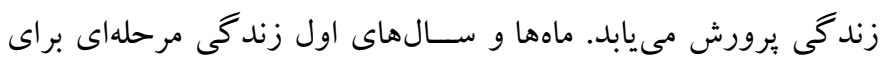

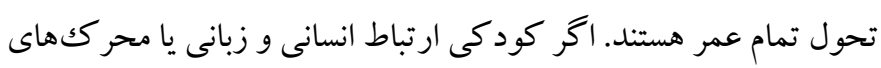

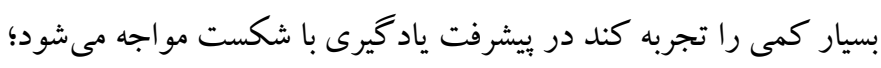

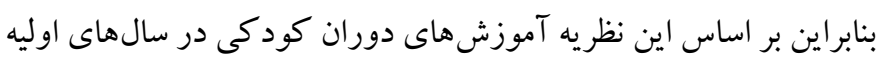

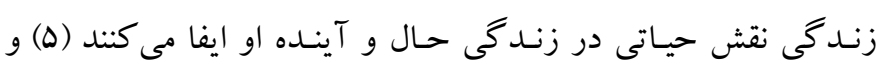

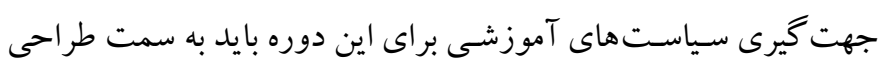

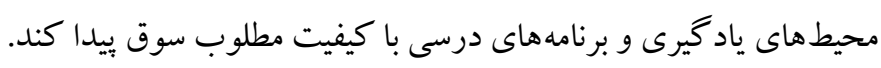

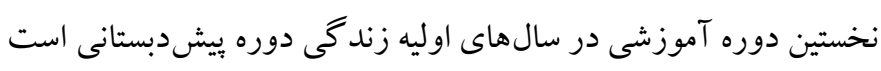

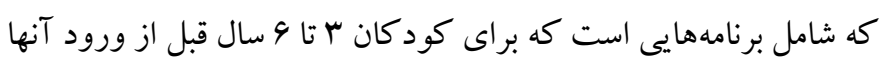

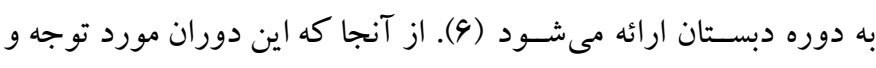

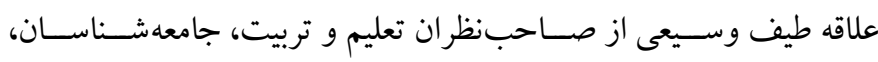

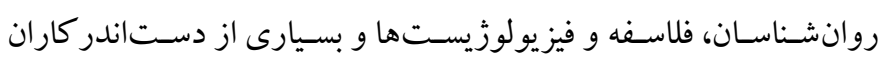

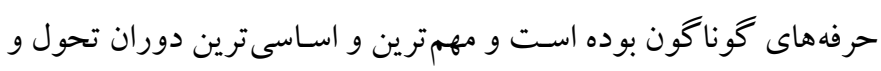

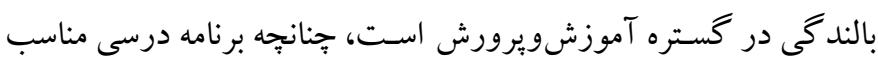

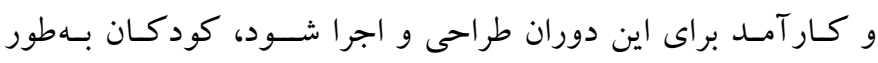

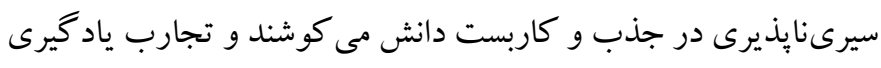

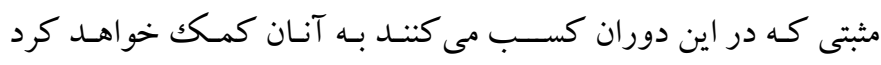

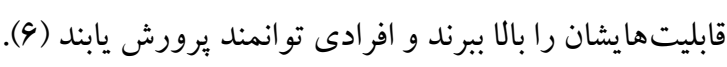

مقلدمه

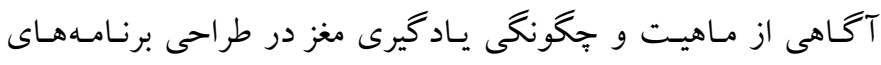

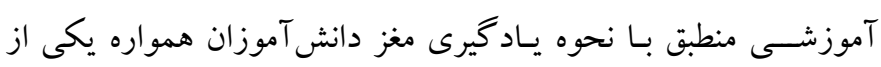

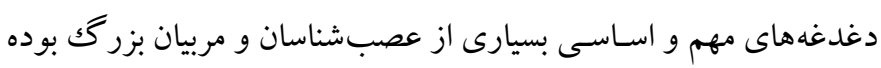

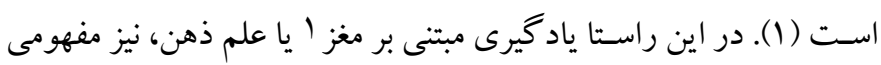

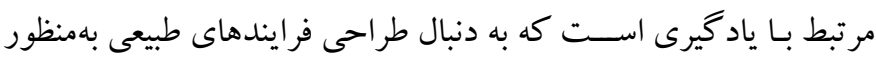

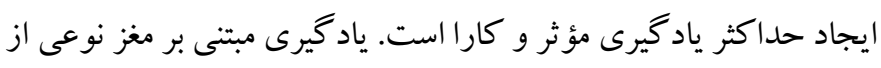

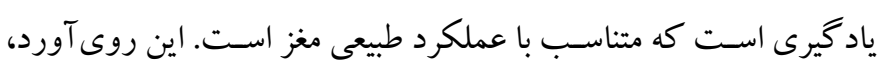

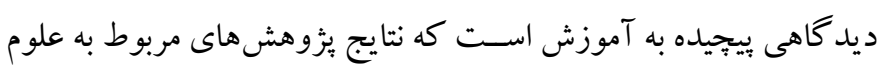

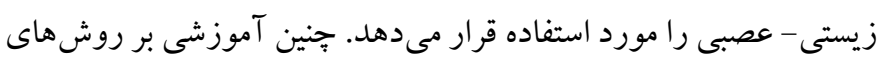

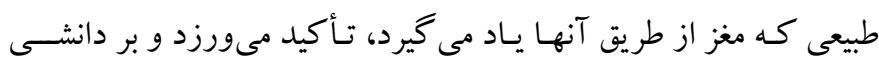

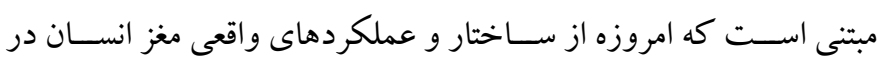
دورههاى تحولى گوناگون وجود دارد (Y).

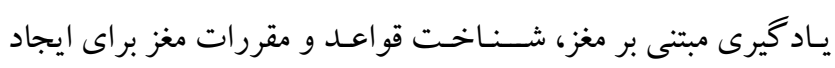

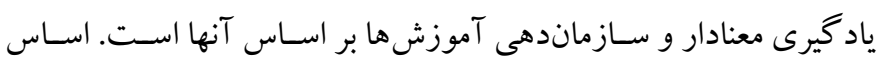

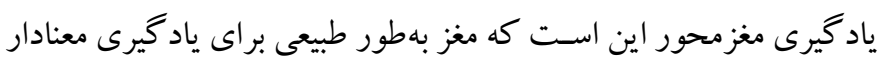

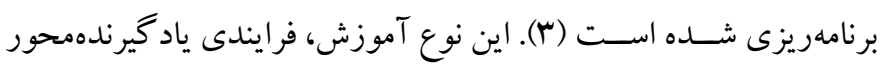

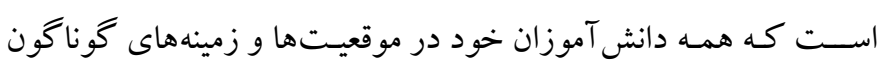

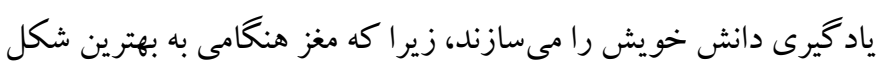

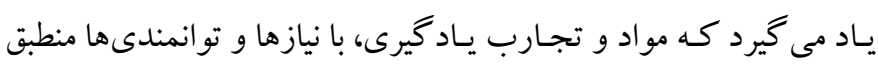

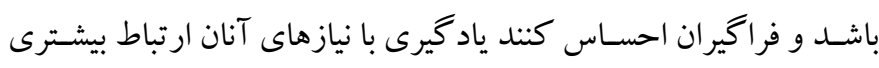

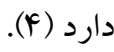

رويكرد مبتنى بر مغز به دوازده اصـل تدريس و ياد گيرى اشاره دارد.

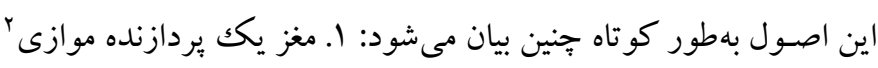

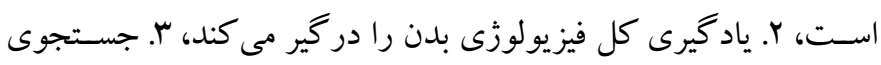

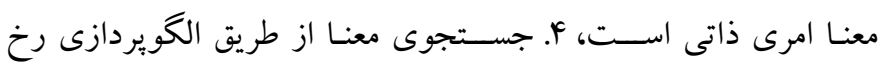

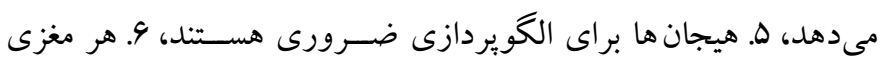

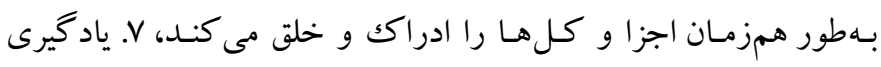

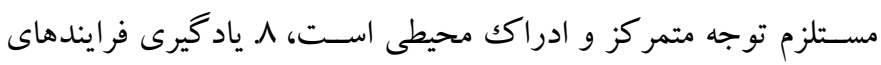

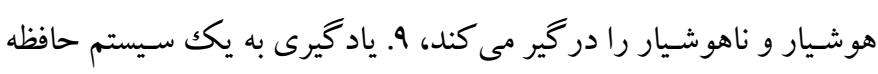

1. Brain-based curriculum

2. Parallel processing 
به راهبردهاى آموزش مبتنى بر مغز اشـاره دارد. كوسـر و بدير (19) در

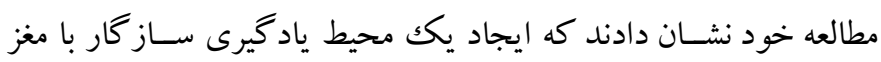

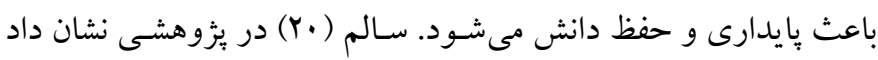

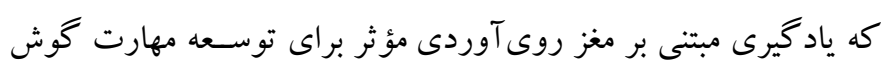
دادن، يادآورى و نظهداشـت حافظه بوده و نقش مثبتى در ايجاد انگيزه

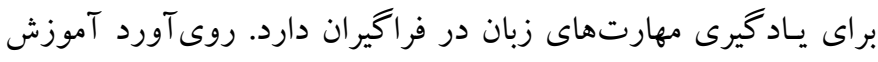

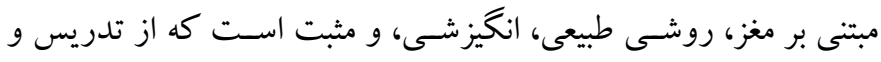

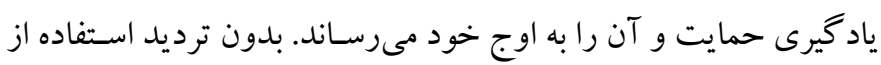

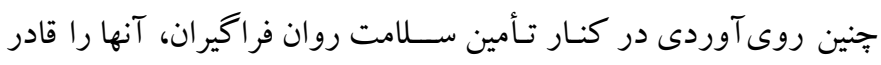

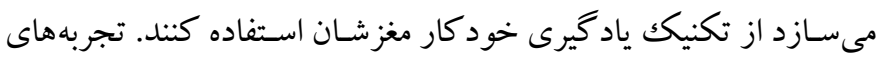

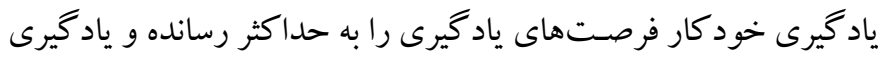

$$
\text { ماند كارتر مىشود (r. (Y). }
$$

با توجه به نقش و اهميت مغز در فرايند ياددهى - يادگيرى و توجه

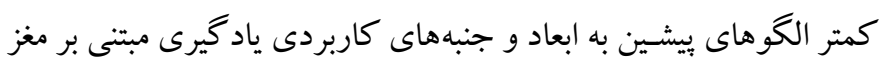

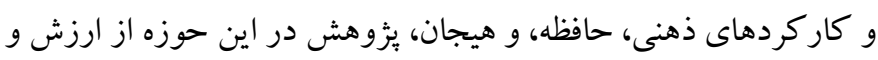

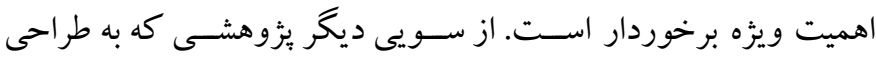

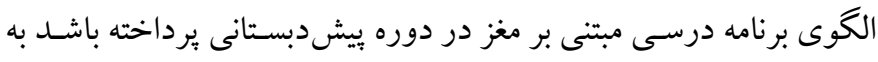

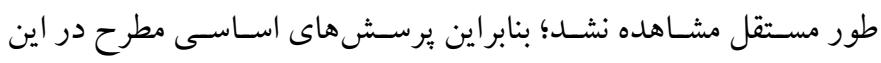

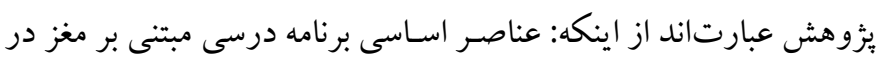

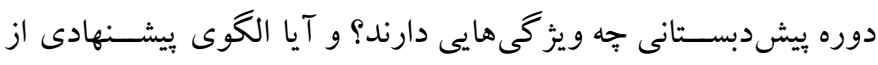

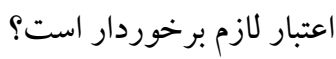

روش

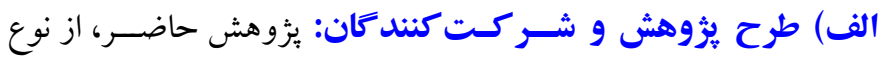

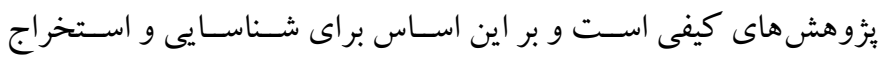

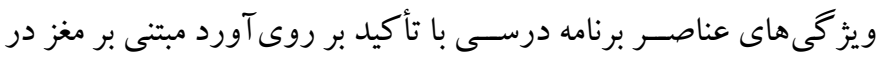

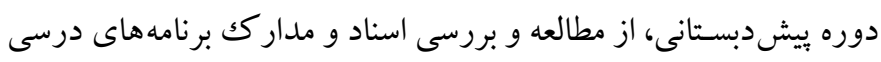

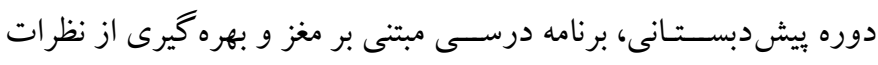

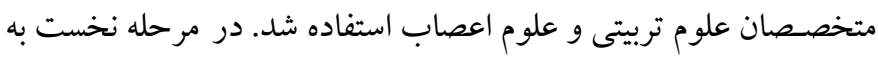

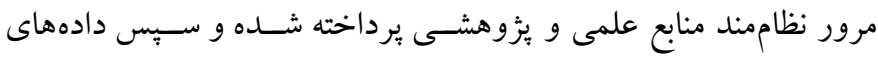

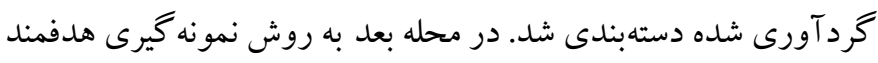
و ملاككمحور، مصـاحبهاى نيمهساختارمند با متخصسصان علوم تربيتى و

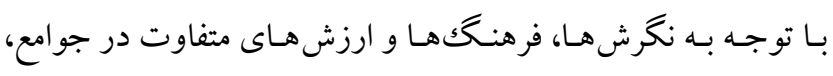
الكوهاى آموزشى مختلفى در مراكز آموزش بيشدبستانى اجرا مىشود.

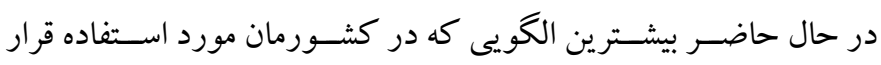

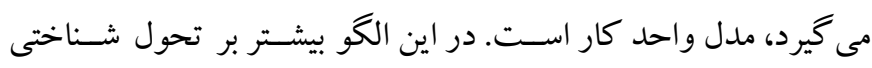

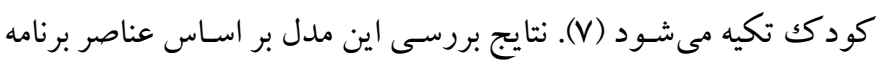

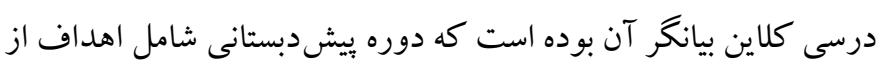

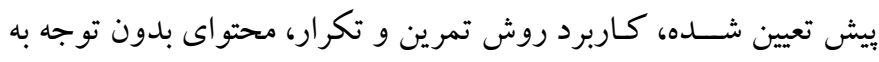

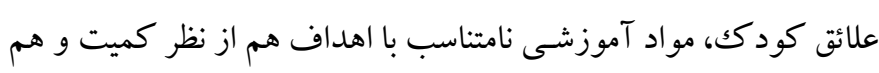

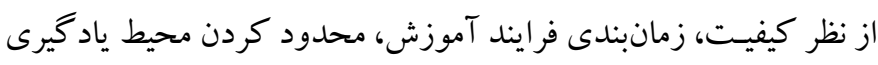

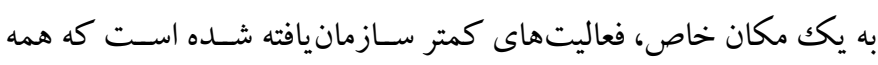

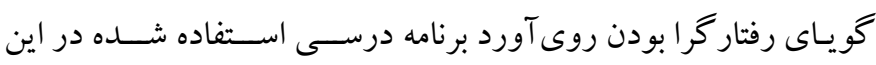

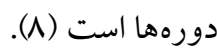
در همين راستا تلاشها و كوششهاى زيادى براى معرفى يكك برنامه درسـى مبتنى بر مغز انجام شـــه كه اغلب به اســتنباط و اســتخراج

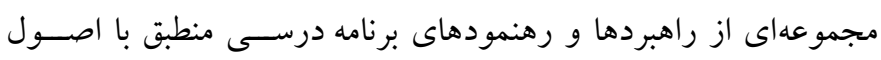

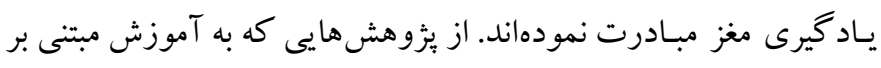

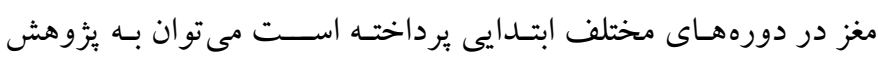
محمدى فارسـانى (9)، نورى و مهرمحمدى ( • (1)، تلخابى (1) (1)، اشـــاره

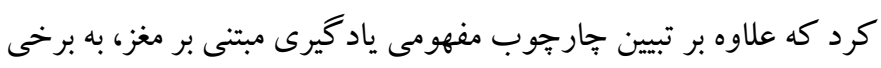

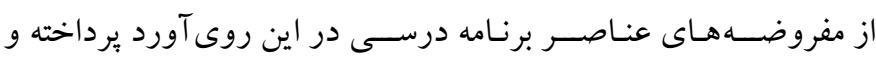

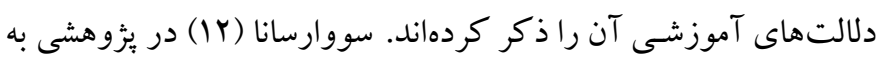
بررسى تأثير ياد گيرى مبتنى بر مغز بر در كك مفاهيم رياضى دانش آموزان

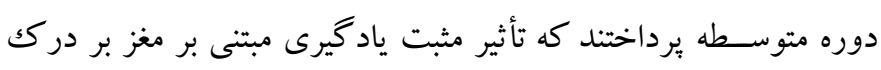

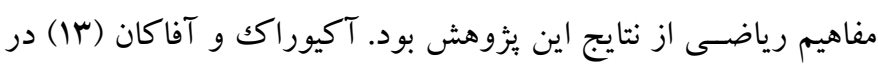

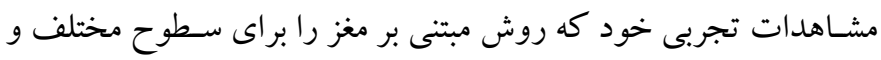
موضـوعات مختلف در كلاس به كار گرفته بودند، دريافتند كه نمرات

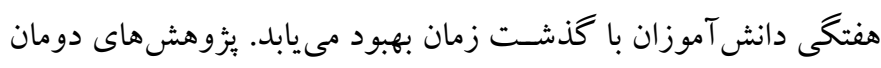

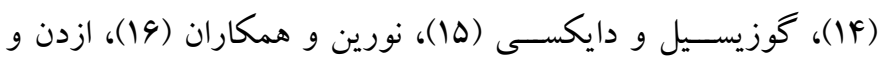
كولتكين (IV) از جمله يثزوهشهايى هسـتند كه آموزش با با روى آورد

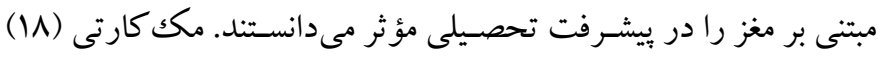

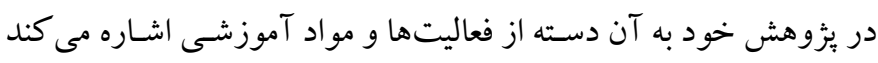

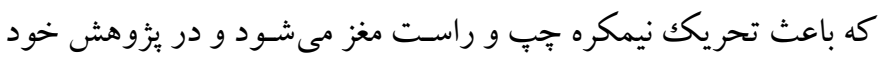


صـاحبنظران و متخصـصـان علوم اعصـاب و علوم تربيتى و برنامهريزان

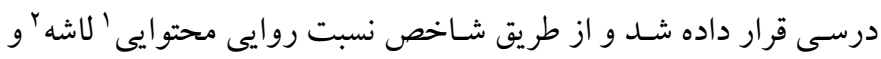
شاخص روايى محتو ايى ‘ميز ان اعتبار الكو بر آورده شد.

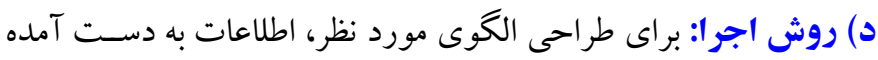
در همه مر احل كنار هم قرار داده شـده و تجزيهو تحليل دادهها انجام شد. اين اطلـاعات عبارت اســت از: ا. اطلاعات به دســت آمده از مطالعه

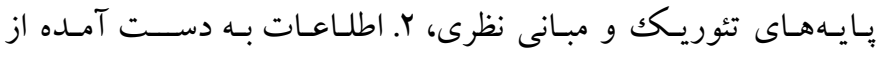
يُزوهشهاى انجام شده در داخل و خارج از كشور، ب. اطلاعات به دست

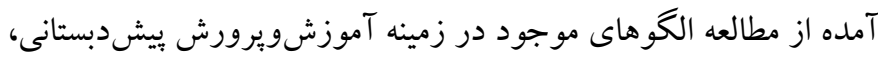
f. اطلاعات به دست آمده از مصـاحبه با متخصصـان علوم تربيتى، علوم اعصـاب، و مرييان. در بايان با كنار هم قرار دادن اين دادهها با استفاده از

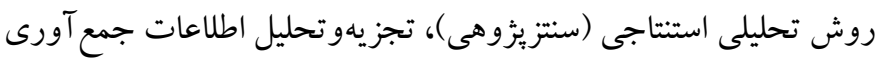

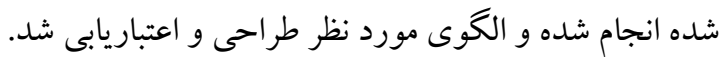

\section{يافتهها}

\section{يرسـش يكم: ويزگى هاى عناصـر اساسى برنامه درسى مبتنى بر مغز}

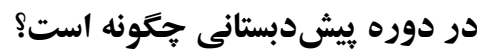

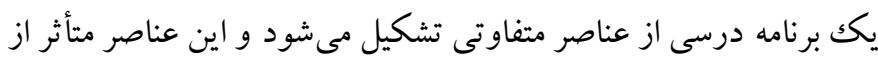
جهت گيرى برنامه درسى اسـت. در اين بخش به توصسيف دادهها و بيان ويز گى هاى عناصـر اســـــى برنامه درسـى (هدف، محتوا، راهبردها، ارزشيابى) حاصل از مطالعه مبانى نظرى، منابع و مطالعات و نيز مصاحبهها

$$
\text { يرداخته مى شود. }
$$

الف) اهداف: دادههاى حاصـل از برسش دئ ديد گاه مربيان و متخصصين در خصسوص اهداف برنامه درسسى مبتى بر مغز در جدول او Y خلاصسه
علوم اعصـاب با تنظيم وقت قبلى انجام شــــ و مؤلفهها و ســاختارهاى مناسـب الكو شـناسـايى شد؛ بنابر اين بستر يزوهش شامل منابع منابع و مطالعات

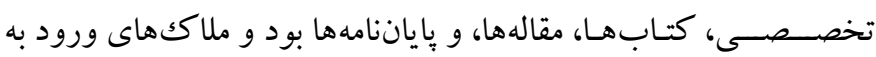
مصـاحبه با متخصسصـان نيز داشـتن دانش و تخصس و نوشـتن مقالات و تأليف كتب در حوزه علوم اعصاب و علوم تربيتى بود. تمامى مصاحبهها ثبت و ضـبط و مورد تجزيهو تحليل قرار كرفت. مصـاحبهها ها دقيقه تا

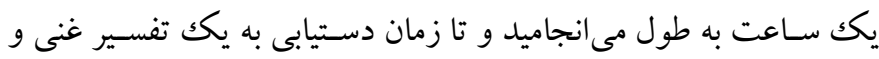
عدم يديدار شـــن دادههاى جديد و به عبارتى تا اشـباع دادهها ادامه

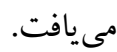
ب) ابزار: با توجه به اينكه يُووهش حاضـر در جند مر حله و با بهره گيرى

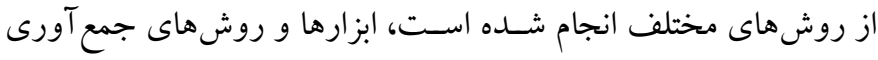

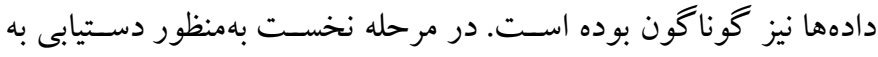

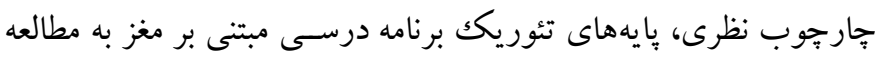

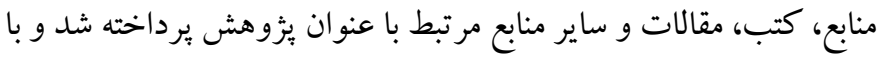

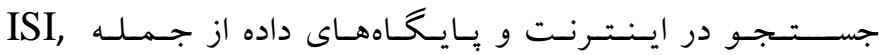
PubMed،Irandoc‘ScienceDirect‘Eric

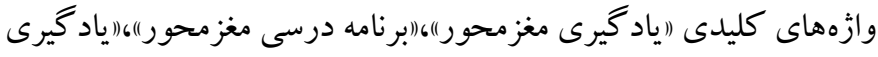

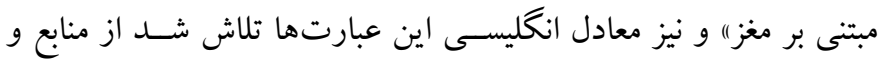
مقالات ير استناد و جديد استفاده شود.

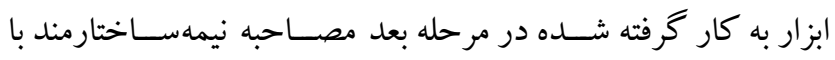
متخصـصـان علوم اعصـاب و علوم تربيتى بهمنظور شــناسـايى مؤلفهها و

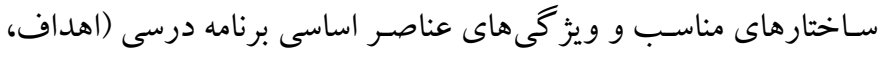

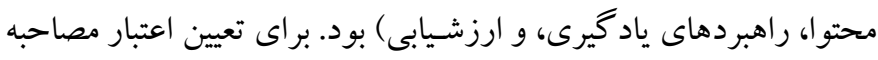

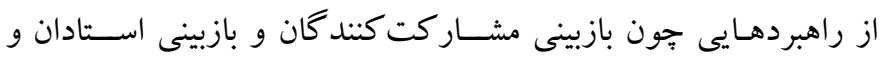

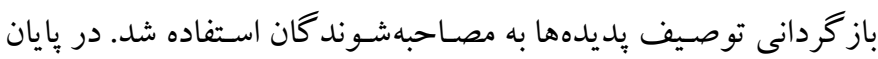
جهت تعيين اعتبار الكوى طراحى شــده، الكوى بيشــنهادى در اختيار 
جدول ا: ديدكاه مربيان و متخصصان درباره اهداف برنامه درسى

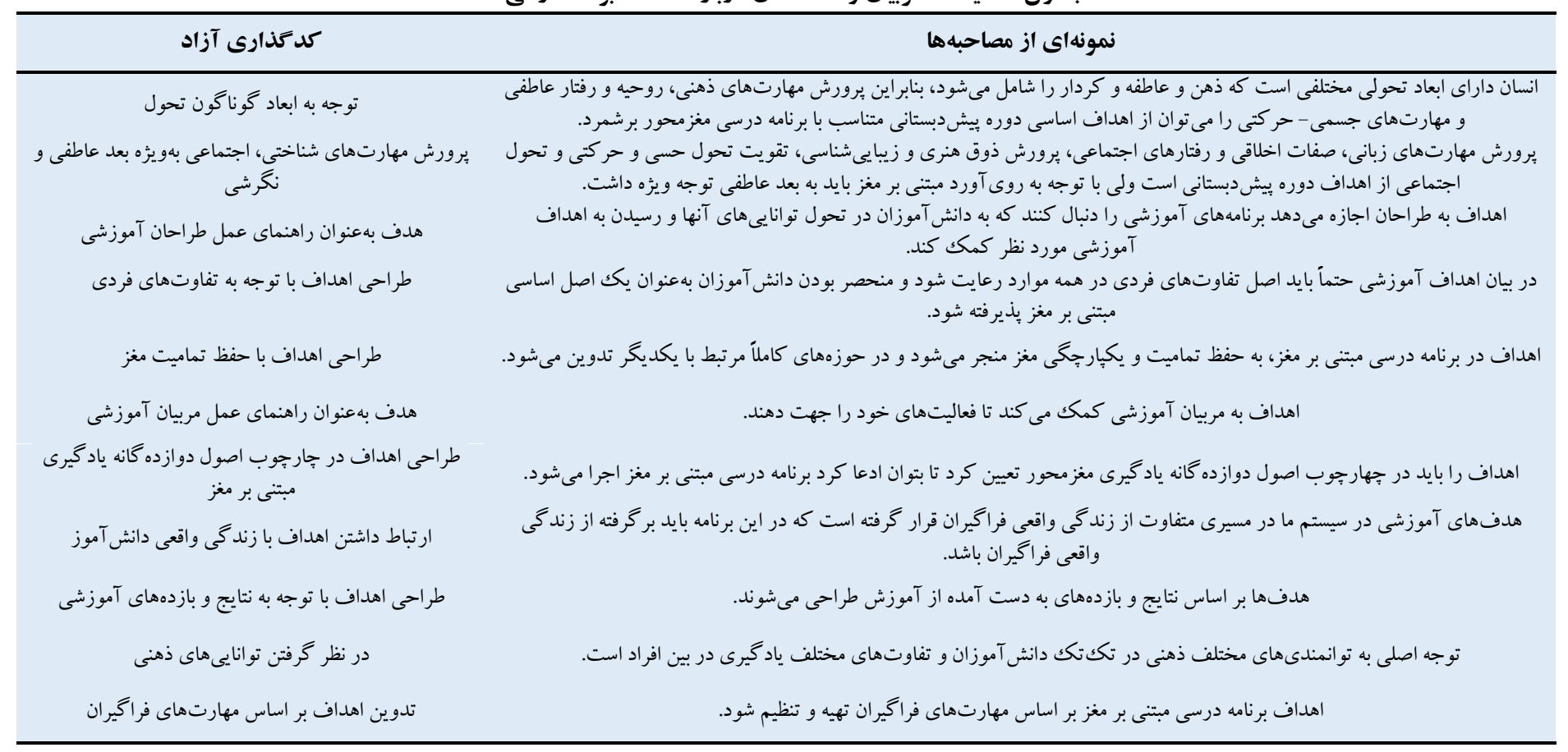

جدول r: مضمونهاى اصلى و فرعى اهداف برنامه درسى

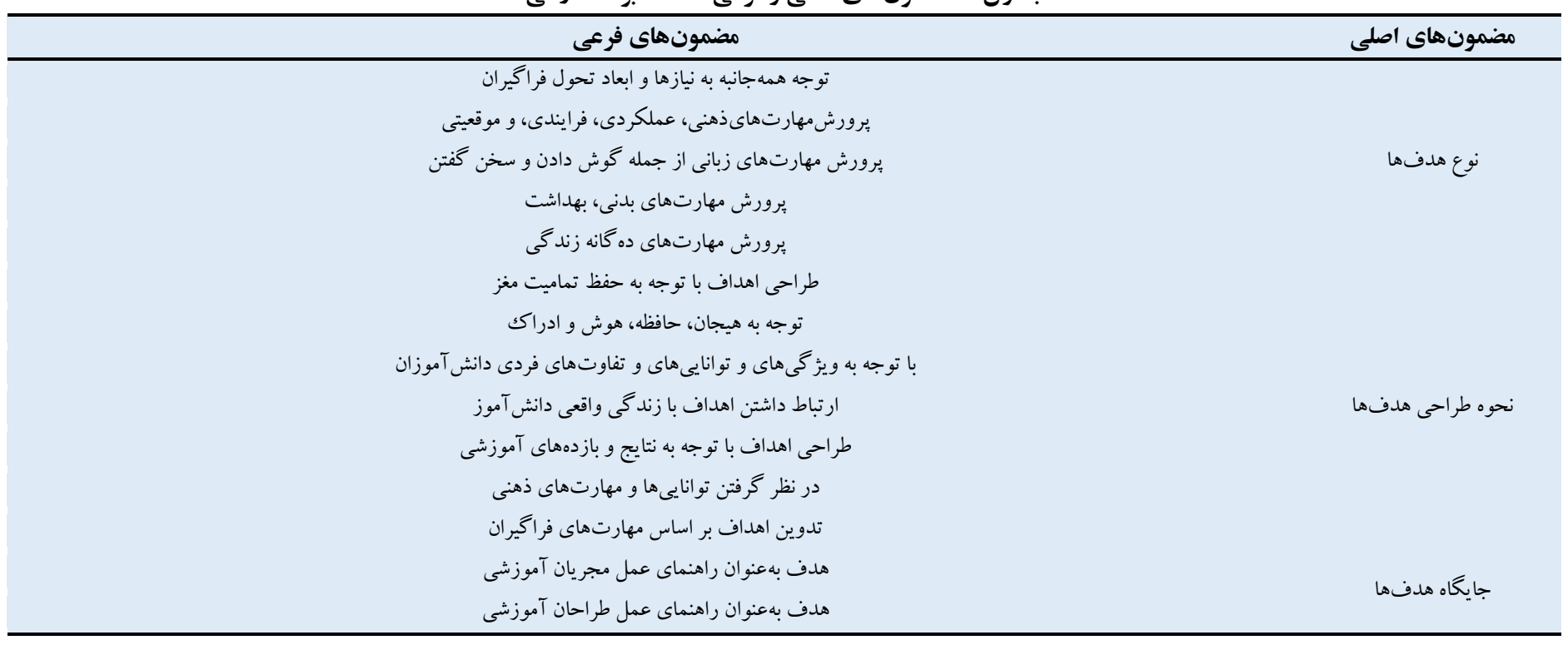

ب) محتوا: دادههاى حاصـل از برسـش ديد كاه مربيان و متخصسصسين دربـاره محتوا و ســازمـاندهى محتواى برنـامسه درســى مبتنى بر مغز در جدولهاى باو F خلاصه شده است:
نتايج بررسى سؤال نخست مصاحبه با مربيان و متخصصان در جدول ا و ب نشــان مىدهـد كـه محورهـاى بـه دســت آمده از تحليل باســـخ

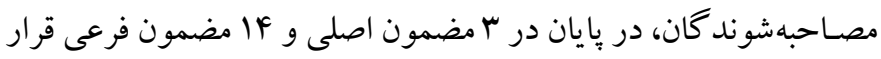
داده شدهاند. 


\begin{tabular}{|c|c|}
\hline كد حذارى آزاد & نمونهاى از مصاحبه ها \\
\hline 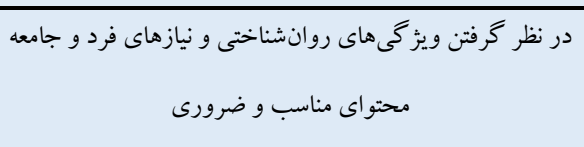 & 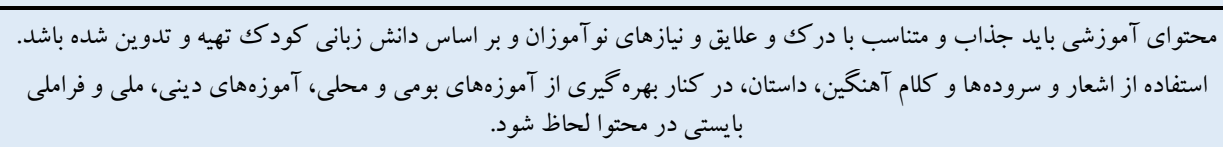 \\
\hline 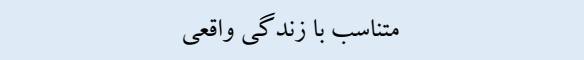 & محتوا بايد برگرفته از تجربه زندگى واقعى نو آموزان باشد. \\
\hline محتواى مبتنى بر موضوعات مورد علاقه نوآموز & محتوا بايد به موضوعات مورد علاقه كودك و نيازهاى آنها باشد. \\
\hline 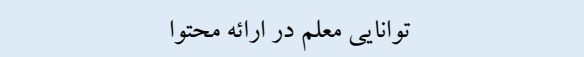 & توانايى مربيان در جگونكى ارائه محتوا مى تواند زمينهساز استفاده از برنامه درسى مغز محور باشد. \\
\hline ي يبوند تحول عاطفى و اجتماعى و فكرى & محتوا بايد بين تحول عاطفى، اخلاقى و اجتماعى و تحول فكرى ييوند برقرار كند. \\
\hline 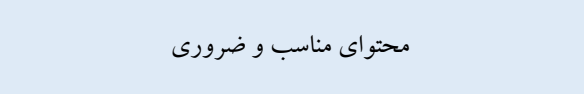 & 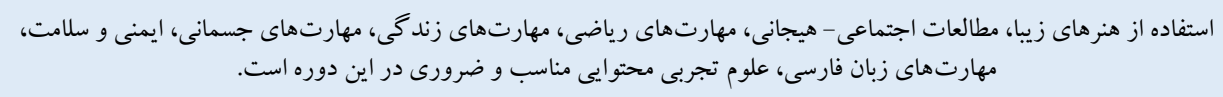 \\
\hline 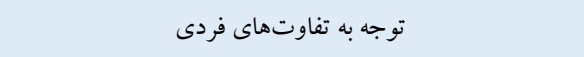 & جون دانش آموزان داراى هوش و ادراكك و حافظه و هيجان متفاو تى هستند، در طراحى محتوا بايد اين مورد را در نظر گرفت. \\
\hline معلم راهنما و دانش آموز فعال & معلم در واقع نقش راهنما و دانش آموزان نقش فعال را بر عهده دارند و كلاس بهصورت تعاملى در خرخش است. \\
\hline فعاليت محور بودن محتوا & ل لازم است محتواى كتابهاى درسى فعاليتمحور باشد. \\
\hline تدوين محتوا بر اساس اهداف روى آورد مبتنى بر مغز & در صورتى كه اهداف آموزشى تماميت يكيارجه مغز را در نظر بكيرند محتوا نيز خواهد توانست نيمكره جِب و راست را تحريك كند. \\
\hline 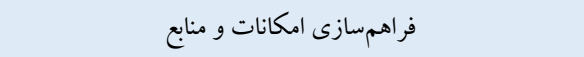 & بايد منابع و امكانات للازم براى اجراى برنامه مبتى بر مغز فراهم باشد. \\
\hline 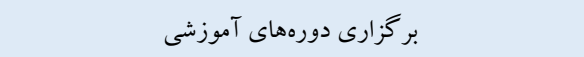 & آموزش مربيان زمينه را براى به كار گيرى اين برنامه فراهم سازد. \\
\hline افز ايش حقوق و مز اياى مربيان & با افزايش دستمزد مربيان مى توان انخيزه للازم را در مربيان ايجاد كرد. \\
\hline به كار كيرى روش تلفيقى در سازماندهى & برنامه درسى مبتنى بر مغزمحتوايى درهم تنيده را مىطلبد. \\
\hline استفاده از فوقبرنامها و فعاليتهاى خارج از كلاس و كتاب & بهتر است برنامهاى درسى اختيارى و فوقبرنامه جهت افزايش كيفيت يادگيرى در محتو آنجانده شود؛ مانند بازديدهاى مختلف و \\
\hline
\end{tabular}

جدول ع. مضمونهاى اصلى و مضمونهاى فرعى محتواى برنامه درسى ديدكاه مربيان و متخصصان

\begin{tabular}{|c|c|}
\hline مضمونهاى فرعى & مضمونهاى اصلى \\
\hline 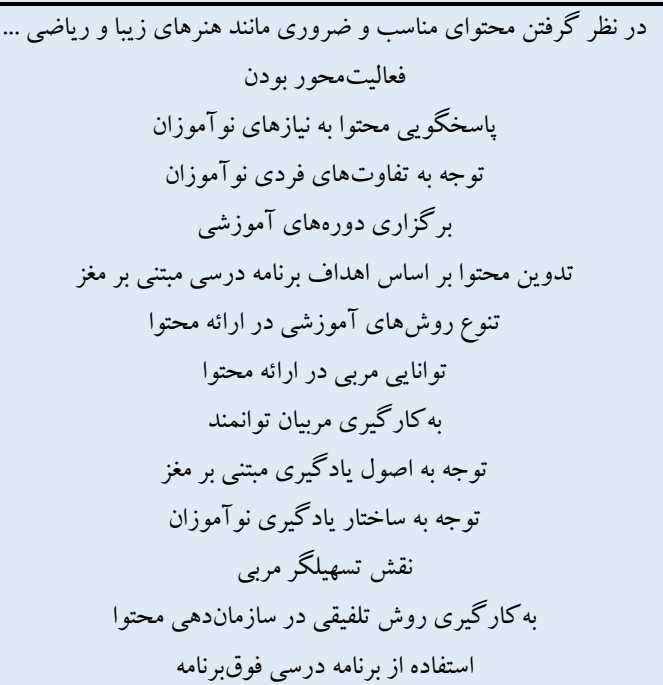 & ويز كى هاى محتو ا محتوا \\
\hline
\end{tabular}

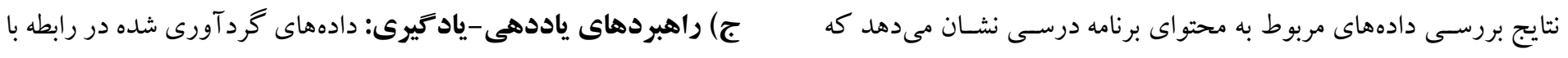

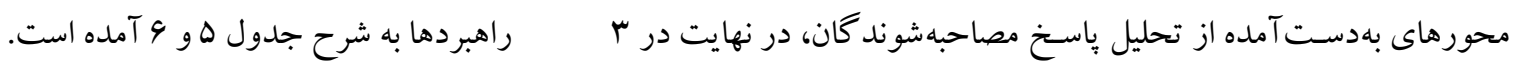
مضمون اصلى و F| أمضمون فرعى قرار داده شدهاند. جدول 0: ديدكاه مربيان و متخصصان درباره راهبردهاى ياددهى -يادكيرى 


\begin{tabular}{|c|c|}
\hline كد كذارى آزاد & نمونهاى از مصاحبه \\
\hline 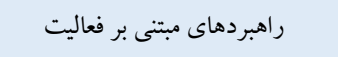 & با توجه به ويز گى هاى نو آموزان، بهتر است نو آموزان از طريق انجام دادن، باز گويى و... ياد بحيرند. \\
\hline راهبردهاى مبتنى بر هنر & 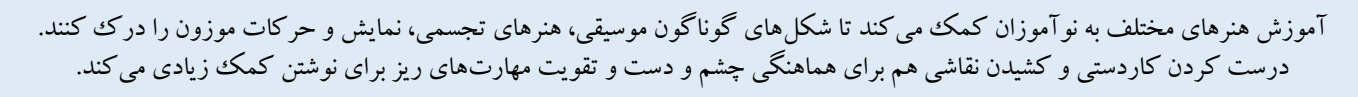 \\
\hline 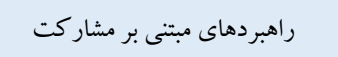 & با تقويت تعاملات گروهى و سازنده، رفتارهاى محترمانه، مسئولانه و همكارى و مهارتهاى بين فردى را به آنها ياد بدهيم. \\
\hline راهبردهاى آموزش مستقيم & انواع مختلف محتوا راهبردهاى ويزهاى را مى طلبد. گاهى للزم است مربى خود بايد فرايند آموزش را به دست گيرد و با برسش و پياسخ و يا توضيح به \\
\hline راهبردهاى ياد گيرى مستقل & نو آموزان براى تبديل شدن به ياد گيرند كانى مستقل و كار آمد بايد از راهبردهاى مديريت زمان و نظارت فردى به خوبى آكاه باشند. \\
\hline 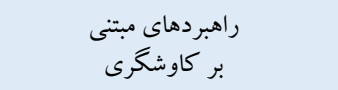 & 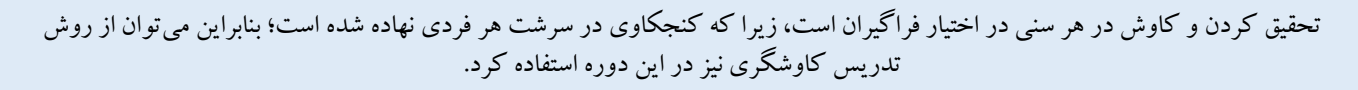 \\
\hline 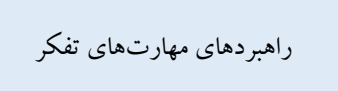 & 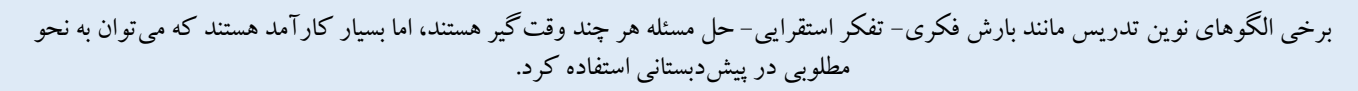 \\
\hline راهبرد مبتنى بر سبكهاى يادكيرى & 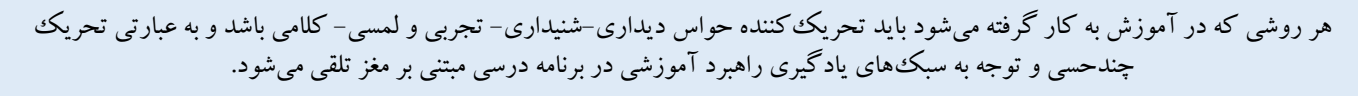 \\
\hline راهبرد كاربست فناورانه و رسانهاى & ارائه رسانهاى-بازىهاى رايانهاى- فيلمهاى آموزشى و گويا-نرم|فزار آموزشى \\
\hline
\end{tabular}

جدول 7": مضمونهاى اصلى و فرعى راهبردهاى ياددهى يادكيرى

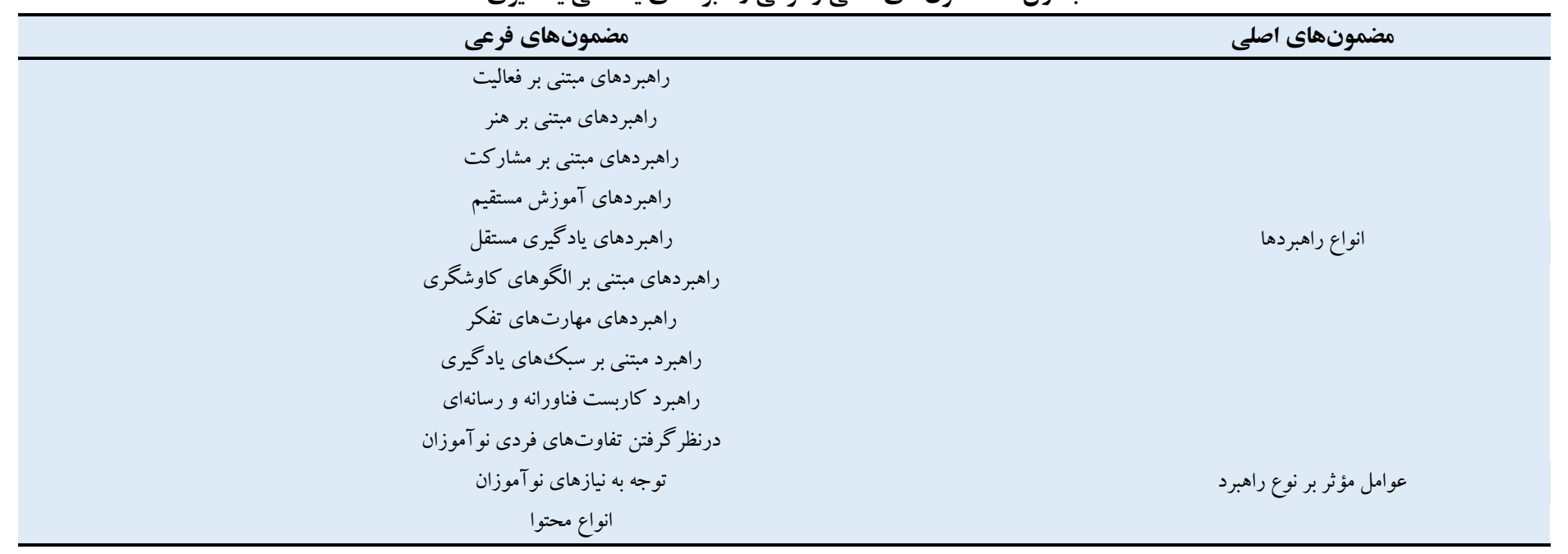

ج) ارزشيابى: دادههاى حاصل از يرسش ديد گاه مربيان و متخصصان علوم تربيتى درباره ويز كى ها و انواع ارزشـيابى در برنامه درسـى مبتنى بر مغز در جدول Vو م خلاصه شده است:
نتايج بررسى سؤال مربوط به راهبردهاى ياددهى - ياد گيرى، با مربيان و متخصـصــان نشـان مىدهد كه محورهاى بهدســت آمده از تحليل پياســخ مصساحبه شوند گان، در نهايت در r مضمون اصلى و Y ا مضمون فرعى قرار

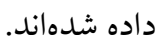




\begin{tabular}{|c|c|}
\hline كدگذارى آزاد & نمونهاى از مصاحبهها \\
\hline متناسب با اصول ياد كيرى مغز محور & ارزشيابى بايد بهصورت مستمر، غير رسمى و بر اساس اصول ياد گيرى مبتنى بر مغز باشد. \\
\hline غيرمستقيم & ارزشيابى بهصورت غيرمستقيم و بدون آكاهى فراگير و با مشاهده رفتار وى انجام مى گيرد. \\
\hline فرايندمدار & 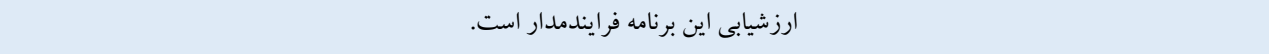 \\
\hline تفاوتهاى فردى فراگيران & بايد از انواع متنوعى از ارزشيابى همانند ارزشيابى آغازين، تشخيصى، تكوينى و بايانى با توجه به تفاوتهاى فردى فراكيران استفاده شود. \\
\hline 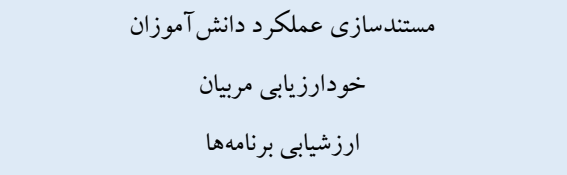 & با مستندسازى فعاليتهاى نو آموزان مىتوان علاوه بر سنجش عملكرد آنها، در راستاى سنجش كيفيت برنامهها اقدام كرد و مربيان نيز \\
\hline بر اساس شايستخىها و قابليتها & ارزشيابى بر اساس شايستخىها و قابليتهاى فراگيران باشد. \\
\hline 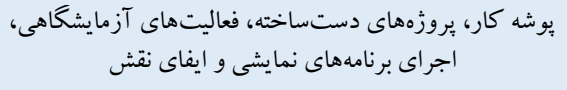 & از يوشه كار گرفته تا يروزههاى دستساخته و فعاليتهاى آزمايشكاهى و اجراى برنامهاى نمايشى و ايفاى نقش بايد ارزشيابى متنوع باشد. \\
\hline 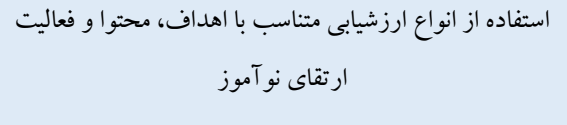 & 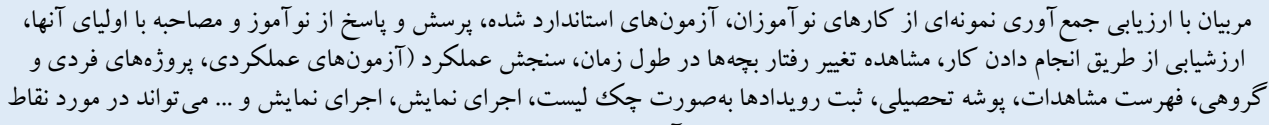 \\
\hline شناسايى نقاط ضعف و قوت & 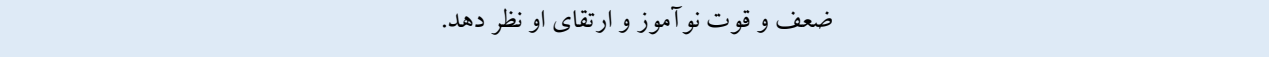 \\
\hline فاصله گرفتن از شيوههاى سنتى ارزشيابى & ارزشيابىها بايد از شيوه سنتى و معمول خارج شده و تنها در سطح دانش و فهم و كاربرد نباشد. \\
\hline
\end{tabular}

جدول 1: مضامين در خصوص روشهاى ارزشيابى

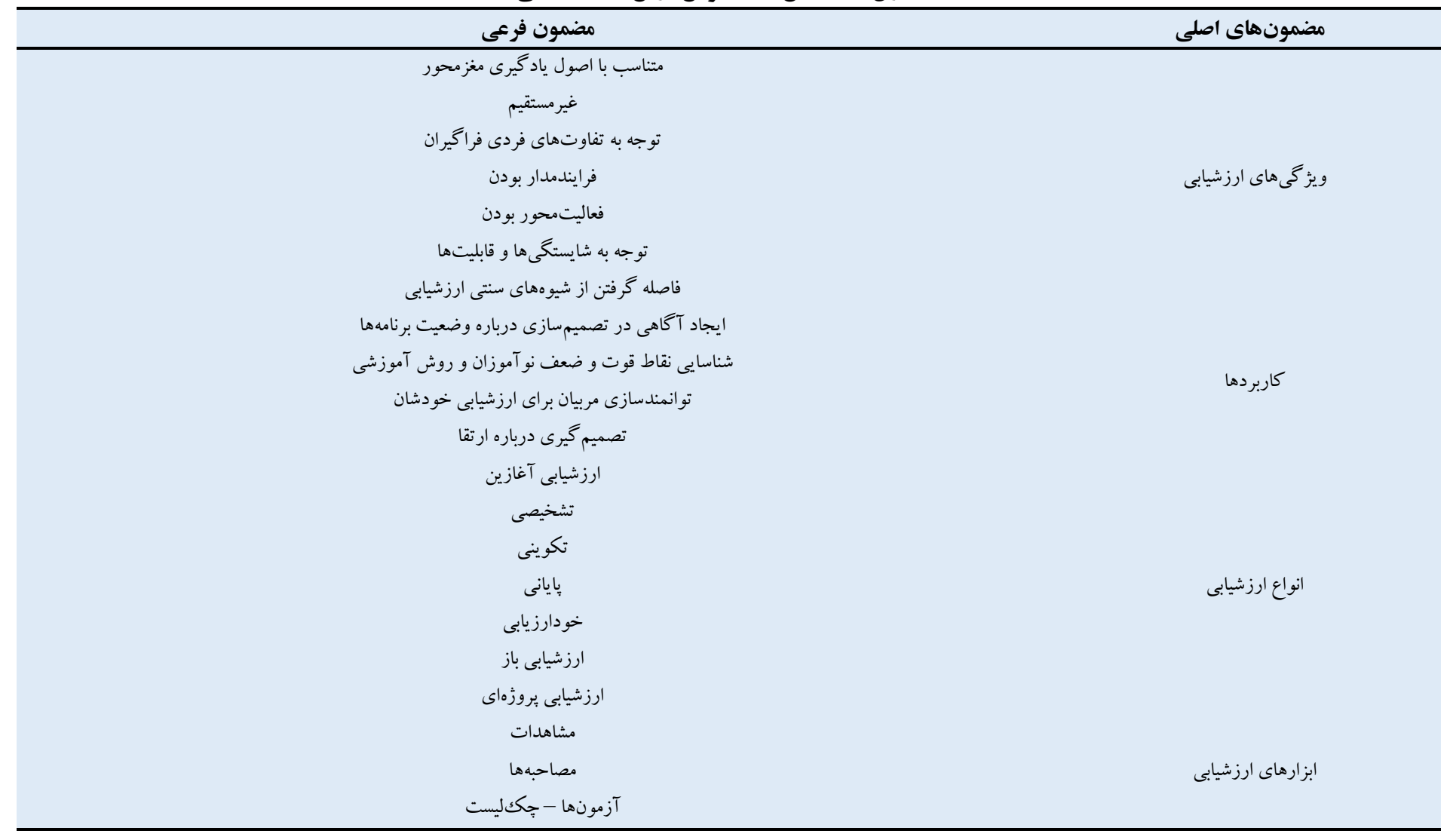


در نظر گرفته شــود؛ V. انواع فرصـتهاى تربيتى و آموزشسى گوناكون

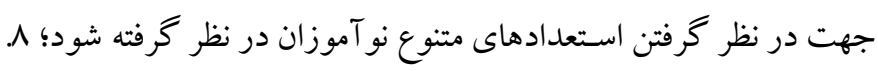

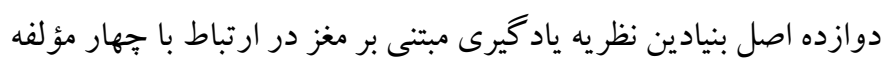

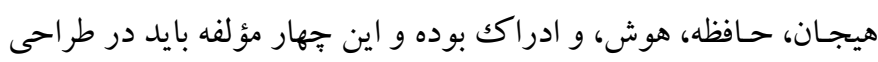

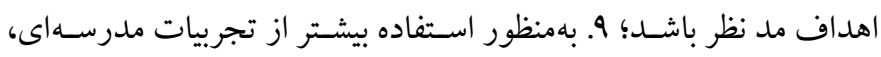

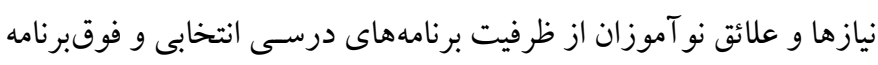

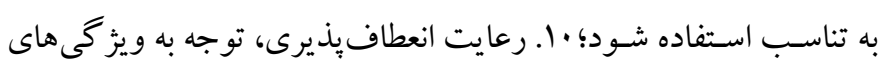

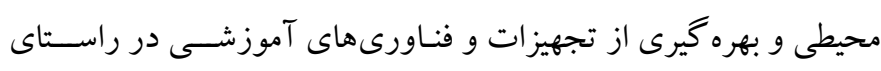

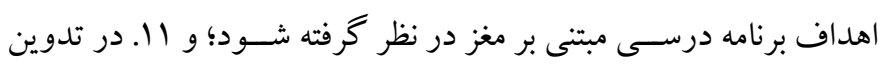

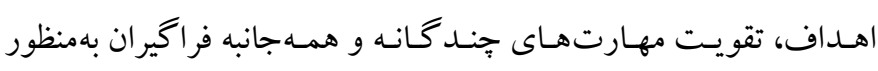

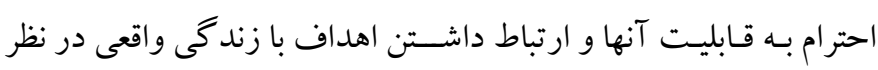
كرفته شود.

محتواى برنامه درسسى مبتنى بر مغز بايد از اين ويز گیىها برخوردار

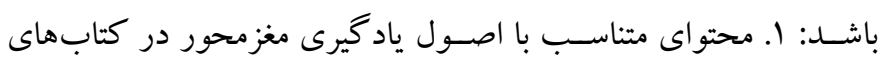

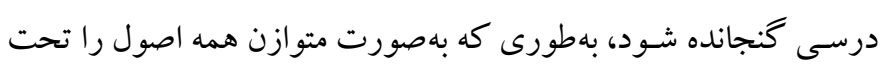

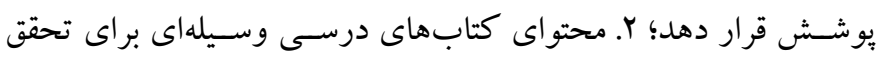

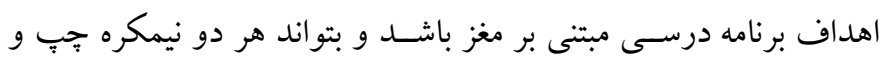

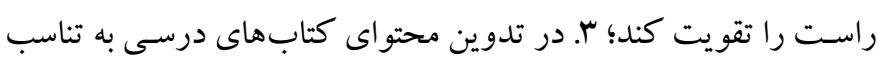

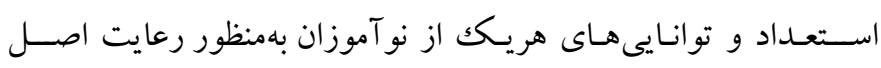

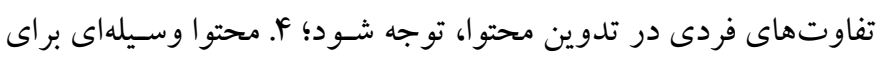

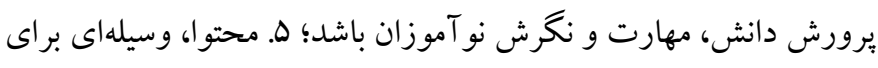

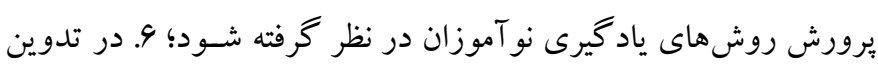

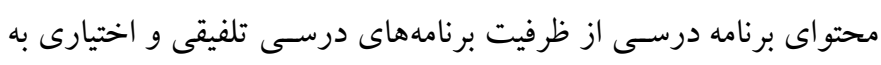

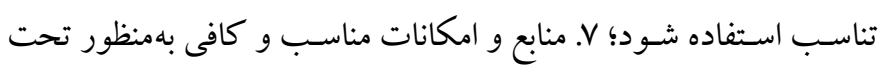

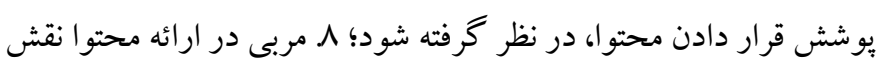

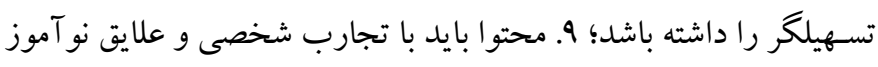

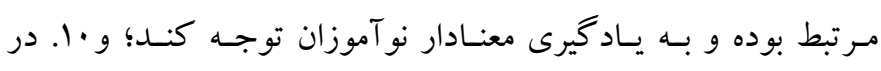

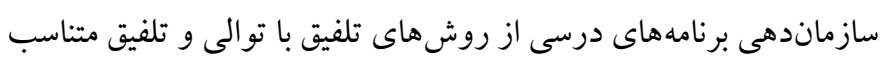

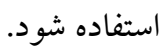
راهبردهاى ياد گيرى مبتنى بر مغز داراى اين ويزّكى ها اسـتـ: ا. بايد

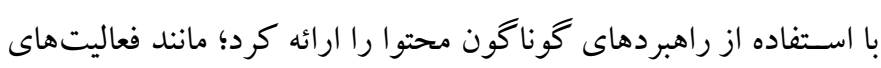

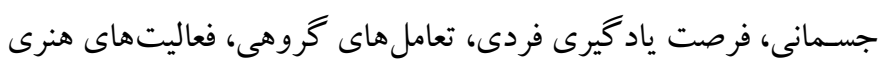

نتـايج بررســى يرسـش مربوط به روش هاى ارزشـــابى، با مربيان و

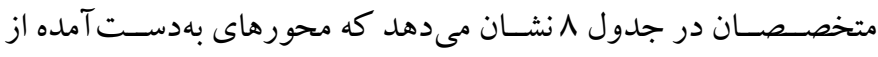

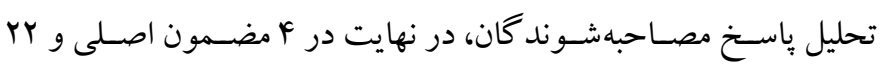
مضمون فرعى قرار داده شدهاند.

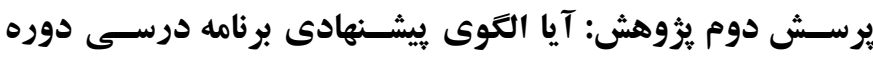
يشيشدبسانى از اعتبار لازم برخوردار است؟

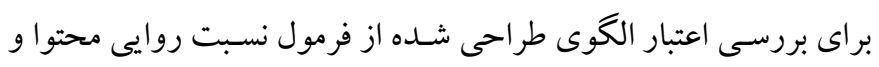

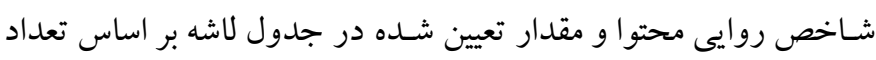

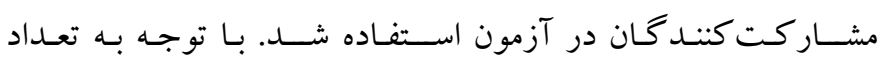

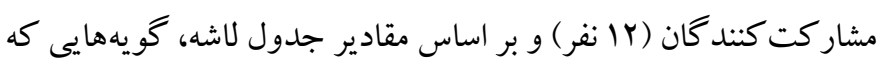

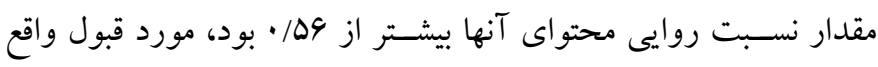

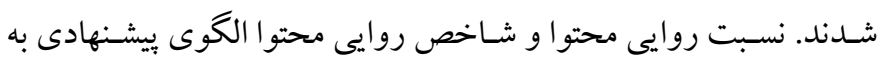

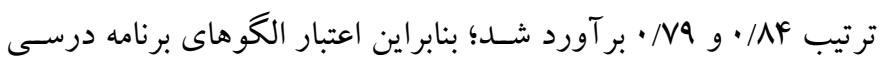

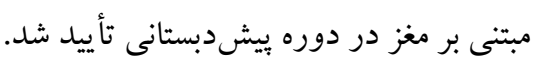

\section{بحث و نتيجه كيرى}

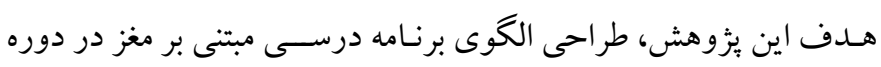

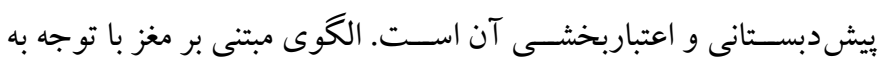

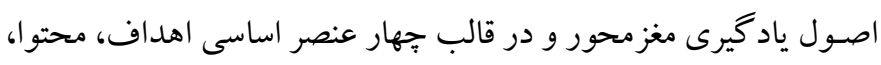

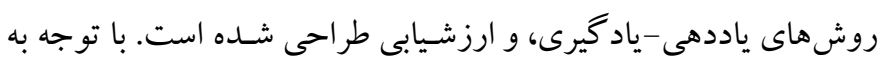

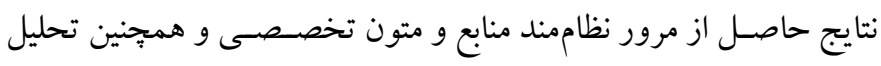

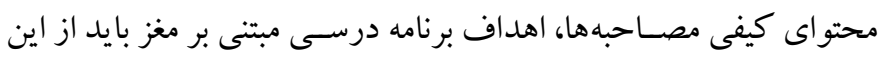

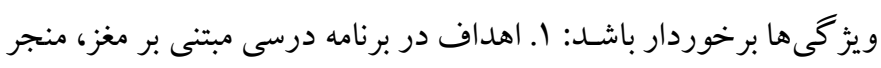

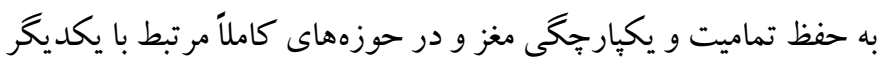

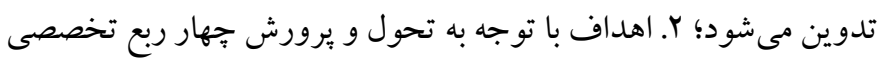

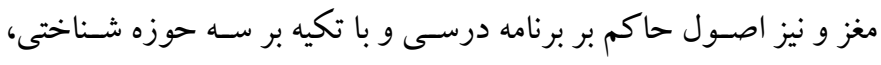

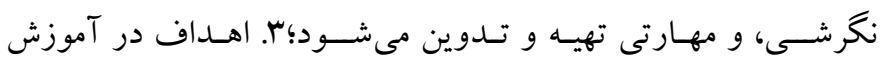

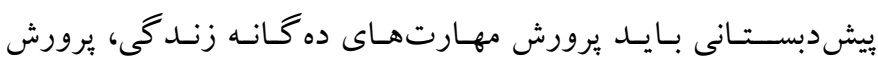

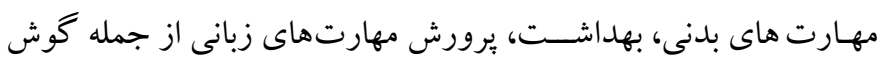

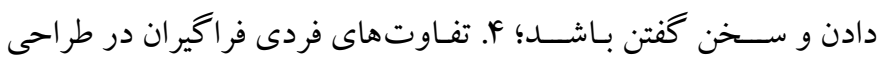
اهداف لحاظ شود؛ ه. تنوع و تكثر در طر احى اهداف با توجه به تفاوتها

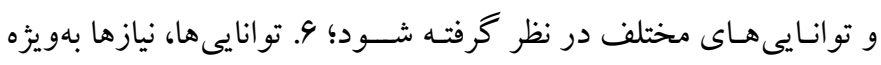
نيـازهاى عاطفى نو آموزان در طراحى اهداف برنامه درسـى مبتنى بر مغز 
اهداف برنامه درسى مبتنى بر مغز در اين يزوهش در راستاى بثزوهش

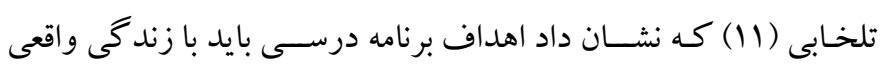

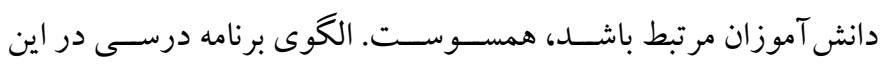

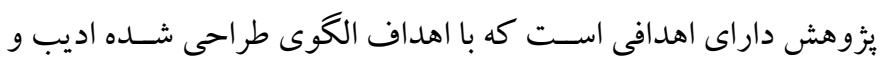

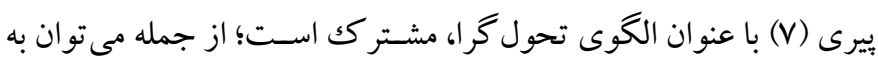

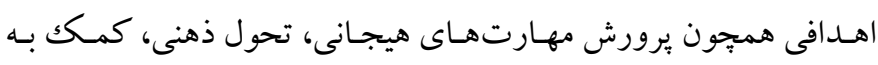

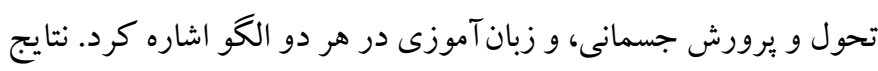

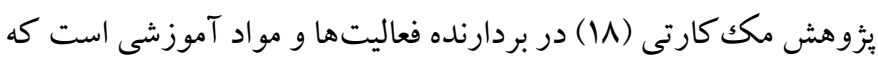

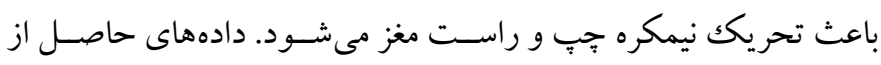
بررسى اسـناد در اين يزوهش نيز نشان داد كه محتو ایى ييشدبستانى بايد

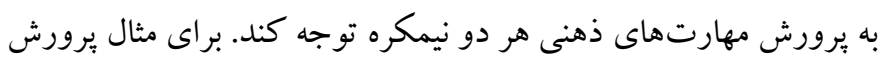

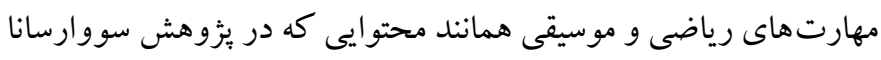

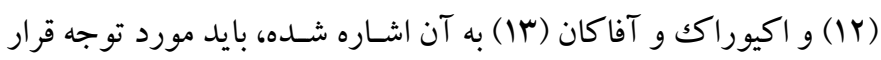
كيرد.

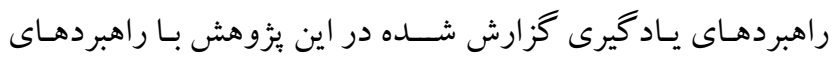

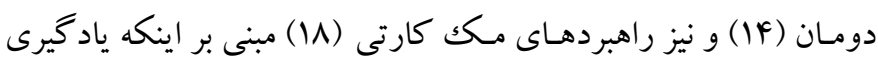

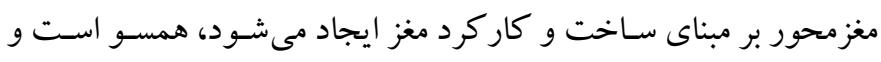

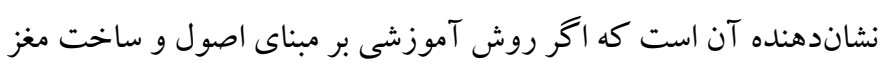

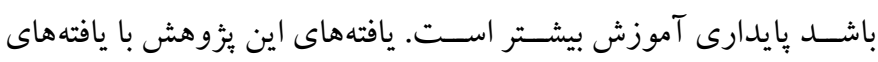

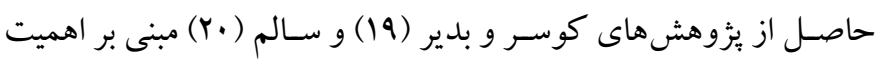

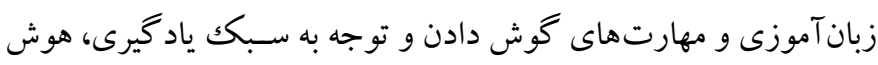

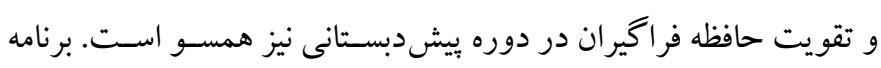

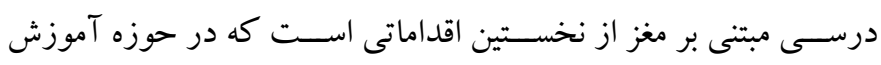

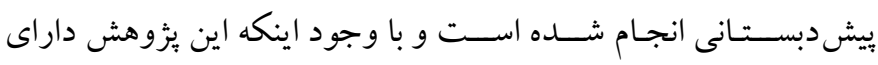

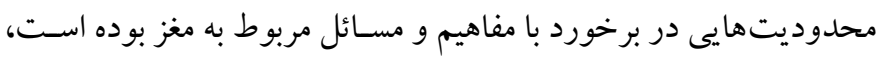

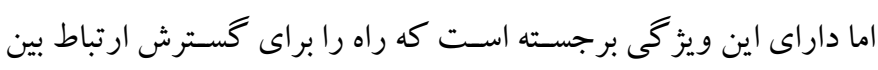
علوم اعصاب و علوم تربيتى باز كرده است.

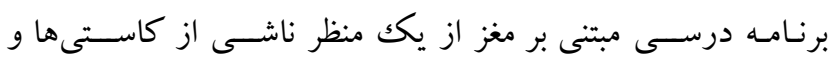

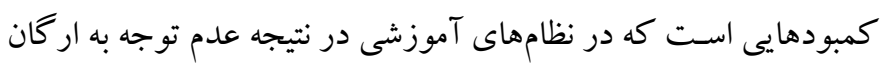

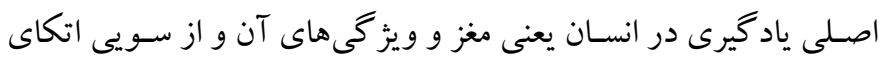

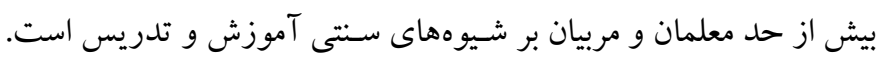

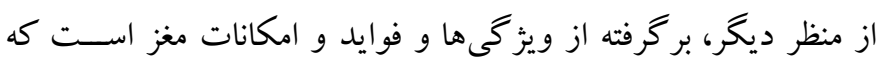

و موسيقى؛ r. كنجكاوى طبيعى ذهن را مىتوان با كشـاكث معنادار و

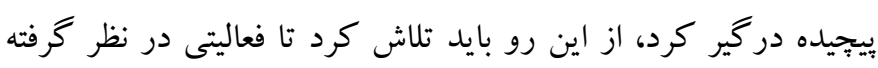
شـود كه جستجوى معنا را بهوسـيله ذهن بر انكيزد؛ س. ياد گيرى مسـتلزم

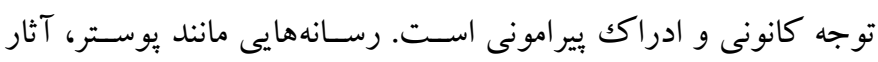

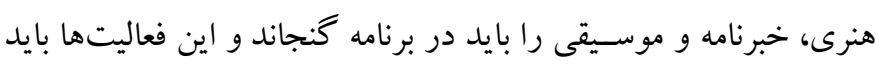

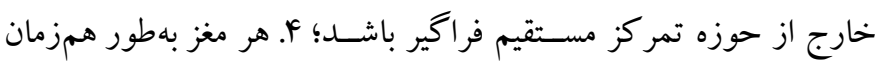

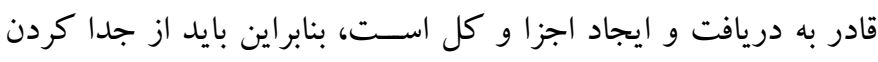

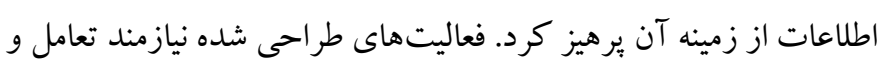

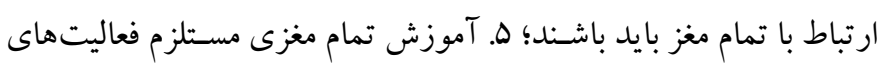

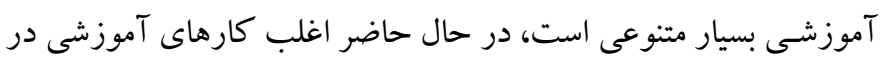

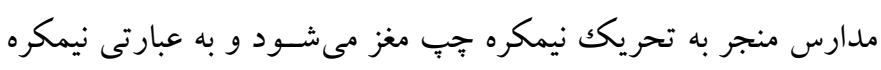

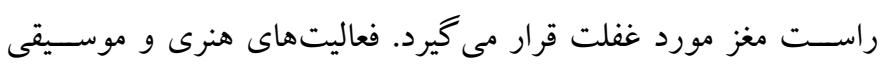

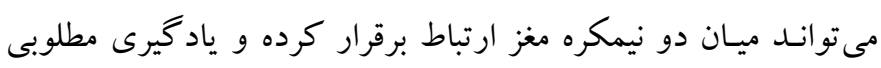

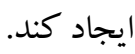

با توجه به نتايج حاصسل از مرور نظاممند منابع و متون تخصصسى و

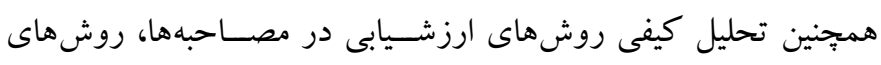

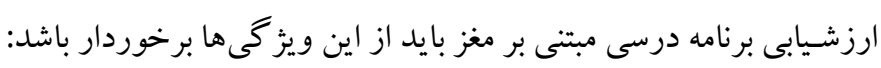

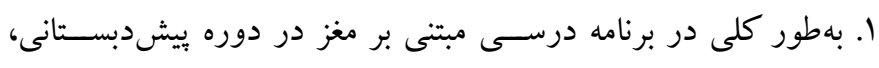

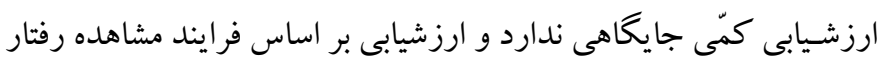

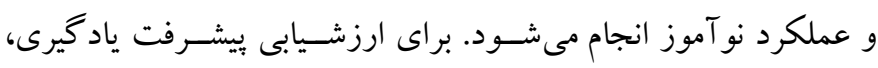

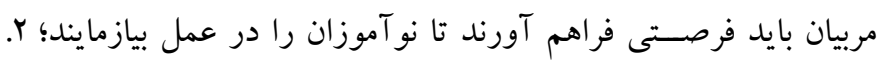

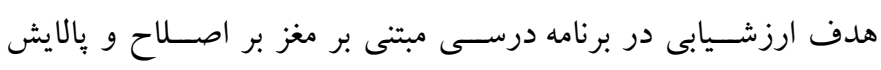

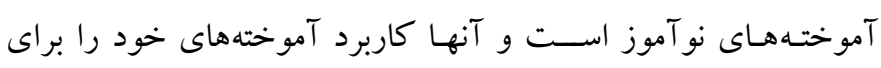

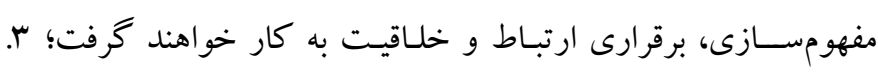

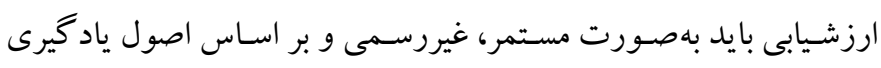

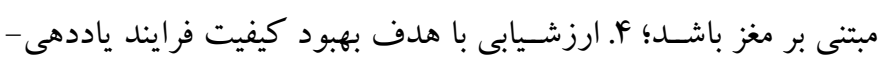

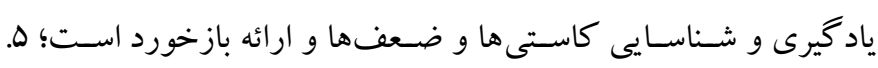
ارزشيابى بهصورت غيرمستقيم و بدون آكاهى فراخير انجام مى گيرد؛ 4.

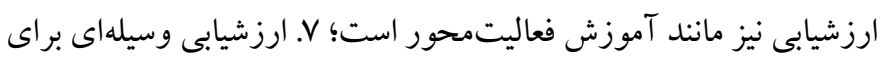

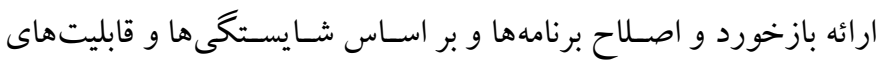

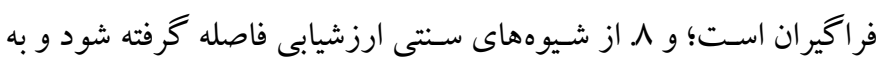
فر آيندمدار بودن توجه شود. 


\section{ملاحظات اخلاقى}

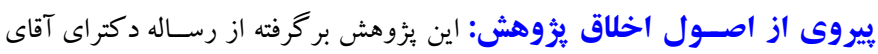

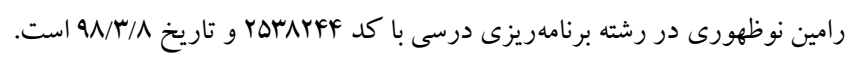

حامى مالى: اين مطالعه بدون حامى مالى و در قالب رساله دكترا انجام شده است.

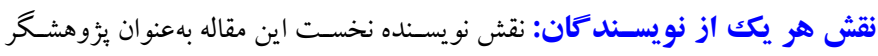

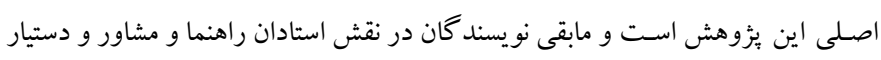
در اين مطالعه نقش داشتهاند.

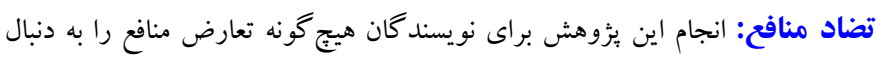

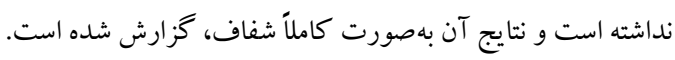

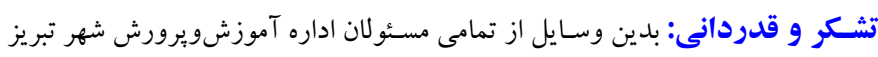

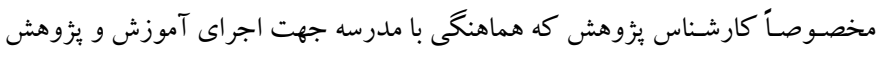

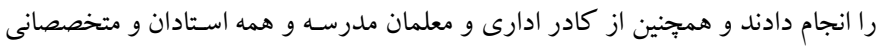

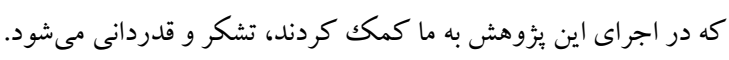

باعث افزايش كارايى و اثربخشى فرايندهاى ياددهى، يادگيرى و برورش

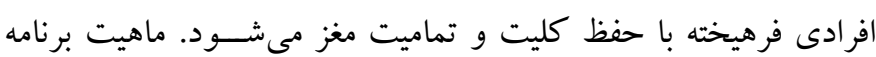
درسى مبتنى بر مغز نشاندهنده اهميت ريشه هاى زيستشناختى رفتار در

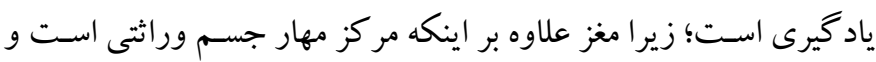

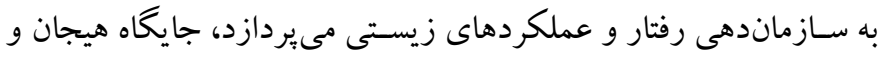

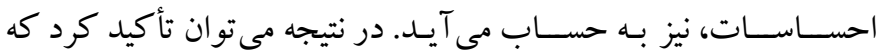

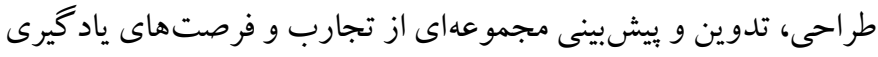

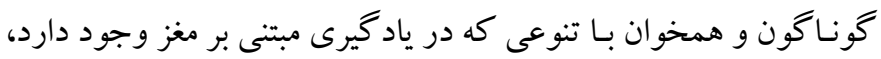

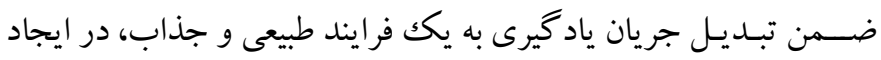

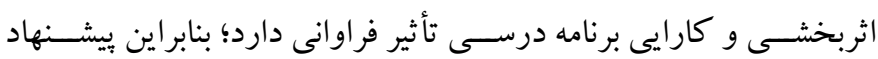

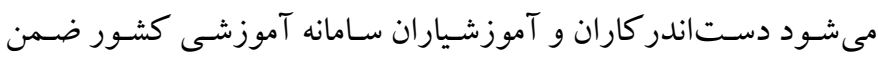

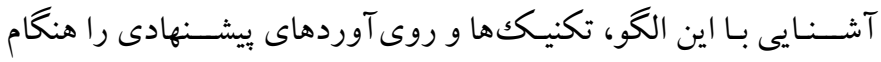

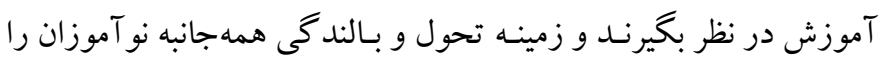

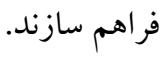




\section{References}

1. Edelman J. Language and Consciousness. Nilipour R. (Persian translator). Second edition. Tehran: Niloufar: 2017, pp: 193. [Persian]. [Link]

2. ElAdl AM, Saad MA. Effect of a brain-based bearning program on working memory and academic motivation among tenth grade Omanis students. International Journal of Psycho-Educational Sciences. 2019; Apr 1:42-50. [Link]

3. Saifi S. Ebrahimigavam S. Effect of brain - based learning on comprehension and pace of learning of Grade 3 primary school students. Journal of quarterly educational inovations. 2010; 9(2): 45-60. [Persian] [Link]

4. Mehrmohammadi M. Curriculum theories, Approaches, Perspectives. Second edition. Mashhad: Behnashr (Astan Quds Razavi). 2010; p: 251.[Persian] [Link]

5. Edie D, Schmid D. Brain Development and Early Learning: Research on Brain Development. Quality Matters. Wisconsin Council on Children and Families. 2007; (1): 4. [Link]

6. Mofidi F. Preschool and Primary Education (Educational Science). Sixth edition. Tehran: Payame Noor University Press. 2007; p: 44 [Persian] [Link]

7. Adib Y. Pirre, R. Optimal pattern for pre-school courses curriculum. Journal of Educational Sciences, 2009; 5 (2): 82- 53. [Persian] [Link]

8. Alavi Langroudi, S. K Karimi B. Nick, A., Review and investigate of pre-primary curriculum model (Case Study), National Conference on Curriculum Change in Education Courses. Birjand University: Birjand. 2013; [Persian] [Link]

9. Mohammadi Farsani F. The brain-based learning environment. Journal of preschool education growth. 2018; Ninth time; No. 179. [Persian] [Link]

10. Nouri A, Mehrmohammadi M. Critical Explanation of the Place of Neuroscience in the Field of Educational Knowledge and Practice. Advances in Cognitive Science. 2010; 12 (2):83-100. [Persian] [Link]
11. Talkhabi M. Brain-based curriculum. Quarterly journal of educational innovations, 2008; No. 26, seventh year. [Link]

12. Suarsana I. Made, W. Ni Putu S. Suparta, I. N. The Effect of brain-based learning on second grade junior students' mathematics conceptual understanding on polyhedron. Journal on mathematics education. 2018; 9(1): 145156.[Link]

13. Akyurek E., \& Afacan, O. Effects of brain-based learning approach on students' motivation and attitudes levels in science class. Mevlana international journal of education, 2013; 3(1): 104-119. [Link]

14. Duman B. The effects of brain-based learning on the academic achievement of students with different learning styles. Journal of Educational sciences: Theory and practice. 2010; 10(4): 2077-103. [Link]

15. Gozuyesil E. Dikici A. The effect of brain-based learning on academic achievement: A meta-analytical study. Journal of Educational sciences: Theory and practice, 2014; 14(2): 642-648. [Link]

16. Noureen G. Riffatunnisa. A. Hijab F. Effect of brain-based learning on academic achievement of VII graders in mathematics. Journal of elementary education. 2017; 27(2): 85-97. [Link]

17. Ozden M. Gultekin M. The effects of brain- based learning on academic achievement and retention of knowledge in science course. Electronic journal of science education. 2008; 12(1): 1-17. [Link]

18. McCarthy B. Using the 4MAT system to bring learning style to schools, Educational leadership, 1990; 48: 31-37. [Link]

19. Kosar G., Bedir, H. Improving knowledge retention via establishing brain-based learning environment. European journal of education studies. 2018; 4 (9): 208-218.[Link]

20. Salem A.A. Engaging ESP students with brain-based learning for Improved listening Skills, Vocabulary retention and motivation. English language teaching. 2017; 10(12):182-95. [Link] 